This item was submitted to Loughborough's Research Repository by the author.

Items in Figshare are protected by copyright, with all rights reserved, unless otherwise indicated.

\title{
Applying a universal content and structure of values in construction management
}

\section{PLEASE CITE THE PUBLISHED VERSION}

http://dx.doi.org/10.1007/s10551-009-0055-7

PUBLISHER

(c) Springer

VERSION

AM (Accepted Manuscript)

LICENCE

CC BY-NC-ND 4.0

\section{REPOSITORY RECORD}

Mills, Grant R., Simon A. Austin, Derek S. Thomson, and Hannah Devine-Wright. 2019. "Applying a Universal Content and Structure of Values in Construction Management". figshare. https://hdl.handle.net/2134/9654. 
This item was submitted to Loughborough's Institutional Repository (https://dspace.lboro.ac.uk/) by the author and is made available under the following Creative Commons Licence conditions.

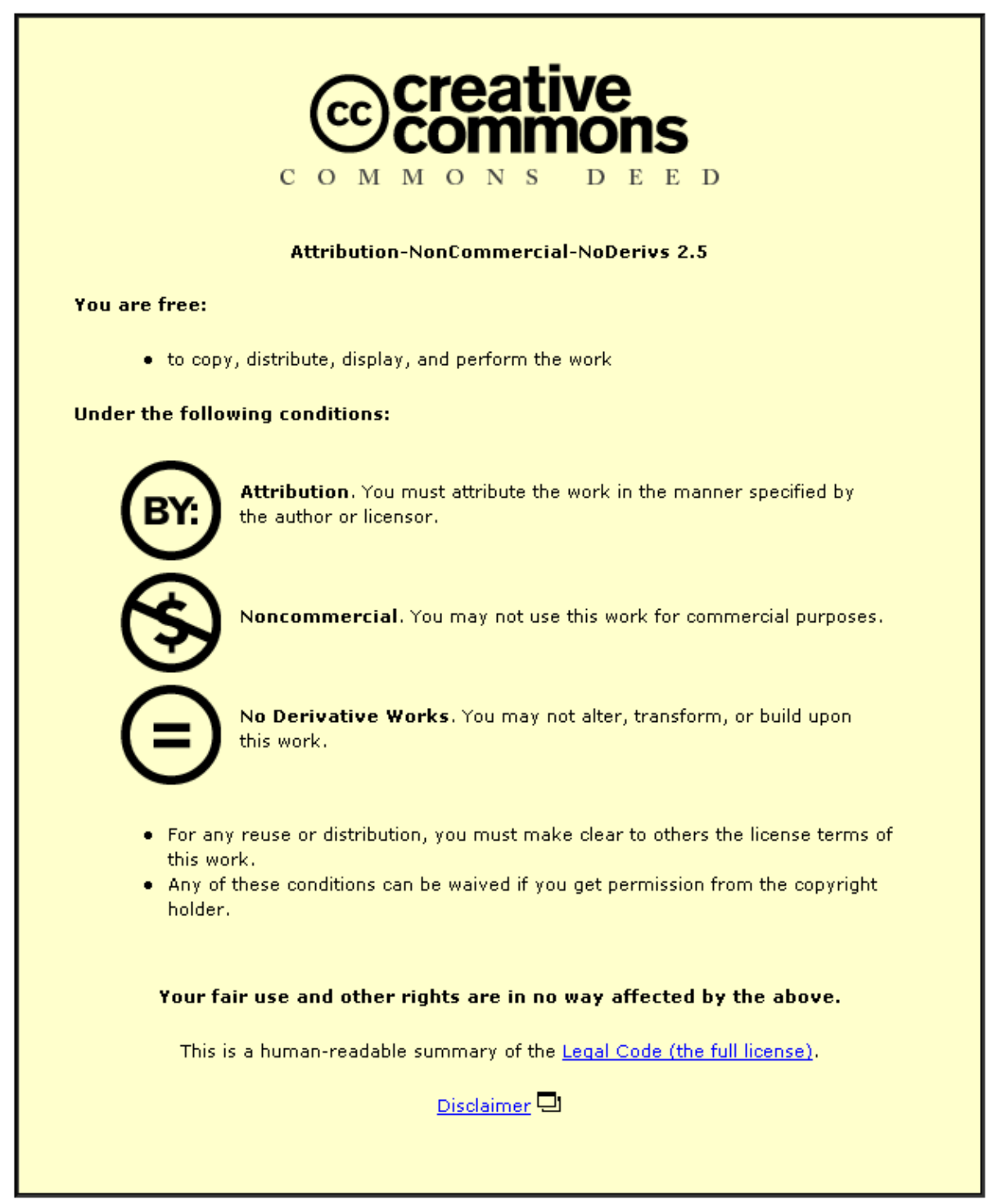

For the full text of this licence, please go to: http://creativecommons.org/licenses/by-nc-nd/2.5/ 


\title{
Applying a Universal Content and Structure of Values in Construction Management
}

\author{
Grant R. Mills, Simon A. Austin, Derek S. Thomson, Hannah Devine-Wright
}

\begin{abstract}
ABSTRACT. There has recently been a reappraisal of value in UK construction and calls from a wide range of influential individuals, professional institutions and government bodies for the industry to exceed stakeholders' expectations and develop integrated teams that can deliver world class products and services. As such value is certainly topical, but the importance of values as a separate but related concept is less well understood. Most construction firms have well-defined and well-articulated values, expressed in annual reports and on websites; however, the lack of rigorous and structured approaches published within construction management research and the practical, unsupported advice on construction institution websites may indicate a shortfall in the approaches used. This article reviews and compares the content and structure of some of the most widely used values approaches, and discusses their application within the construction sector. One of the most advanced and empirically tested theories of human values is appraised, and subsequently adopted as a suitable approach to eliciting and defining shared organisational values. Three studies within six construction organisations demonstrate the potential application of this individually grounded approach to reveal and align the relative values priorities of individuals and organisations to understand the strength of their similarity and difference. The results of these case studies show that this new universal values structure can be used along with more qualitative elicitation techniques to understand organisational cultures.
\end{abstract}

\section{Keywords:}

business, construction, management, project, value, values

\section{Introduction}

This article describes the selection and innovative re-application of existing approach to understanding values that can be used by construction organisations to inform the development of policies, selection of participants, formation and leadership of teams or appraisal of personnel. The Schwartz Values Survey and universal values structure, one of the most advanced theories of human values, has been adapted and applied in this article to access its effect on delivering greater value, building customer-oriented cultures and demonstrating corporate social responsibility (by protecting the various interests of stakeholders). It is hoped that the application of the SVS will allow organisations and teams to further understand the complex social realities that run along side the indus- try's highly adept technical processes and solutions. 


\section{Delivering value}

Government and industry bodies are with increasing frequency exhorting the construction industry, and its clients, to both deliver and demand greater value. These include: CABE (2002, 2003, 2004, 2005), Egan (2002), OGC (2003), NAO (2004a, b), Saxon (2005) and Worpole (2000). Some, for example the Strategic Forum for Construction (Egan, 2002) demands greater stakeholder value through the development of integrated project teams, while others call for the building of cohesive sustainable communities or the creation of attractive spaces and clean and friendly neighbourhoods. More generally, they imply a move from simple management notions of optimising time, cost and quality to a more sophisticated appraisal of the impact of the built environment on diverse stakeholder needs and expectations.

An appraisal of literature reveals a lack of clarity and consensus on what exactly is meant by 'value' in the construction context, and how it might be measured. The terms 'value' and 'values' are often conflated, and Thomson et al. (2003) have argued for better definitions of these terms. Where organisations articulate their values, their origins are often unclear or they are confused with strategic goals such as competitiveness and productivity (Webley, 1999).

We support the view that value judgements are distinct from, but ultimately based on, the values of individual and organisational stakeholders. More- over, we argue that it is helpful for groups to identify, share and, where appropriate, align their values. This position is supported by Constructing Excellence, which has recently called for new mechanisms to motivate and align individuals in order to deliver value to individuals, organisations, institutions, industries and society at large (Saxon, 2005).

As with value, such a position begs the question of how to go about it - especially when dealing with often unspoken feelings and beliefs. We suggest that the process can be assisted by starting the dialogue with the capture, analysis and discussion of the values priorities of individuals and groups using a method based upon Schwartz's theory of universal human values (Schwartz, 1992). Before explaining our choice of this approach in Section 'Values theory', we examine the broader business literature for arguments of the merits of understanding values.

\section{The benefits of organisational values programmes}

This section reviews management literature relating to individual, organisational and project values, and balances the positive and negative arguments of their use as a means to deliver business success.

\section{Organisational values and business strategy}

Over the last 50 years, many business management and academic authors have contributed to the debate on whether high performance cultures are those that have strong integrated values. Peters and Waterman (1982) are well known for emphatically pronouncing strong shared values as the core of an excellent corporate culture. However, their findings have been superseded by more rigorous studies, for example Kotter and Heskett's (1992) study of 207 US firms found that an organisation's strong values can drive either high or low performance, depending on that organisation's ability to align with its market and adapt its strategies and practices accordingly (Kotter and Heskett, 1992). We would agree that peoples' personal values should form the basis 
for under- standing organisational values, because strategy is relatively easy to change in comparison to individuals' beliefs and attitudes. For example, McDonald (2002) sees strategy formulation being informed by the persisting cultural values of an organisation, while Hofstede (2001) believes, 'adapting the strategy is usually simpler and cheaper than trying to adapt the culture' (p. 408).

According to Handy (1993), the culture and leadership style of an organisation can be typified as a continuum ranging from a power culture, which has a founder who sees his/her own values strategically forming the basis of all organisational decisions, to a person culture, where individuals work autonomously making decisions framed by their own values. Consequently, the extent of perceived autonomy and control should be recognised when managing people and formulating values and strategies. This is implicit within the field of strategic business management, where organisational decision makers build their strategies in various ways. Bailey and Johnson (1992) and McDonald (1996) for example, state that business managers select a mix of: (1) highly rationale planning processes, developed using data to derive optimum solutions; (2) existing shared cultural frames of reference and common values; (3) consensus building approaches where no one stakeholder has significant influence over any other; (4) antonymous subgroups and committees that address specific problems with- out need for a highly structured overarching system; (5) adherence to statutory codes and regulations or (6) an emphasis upon strong visionary leadership.

Whilst these factors are important, they do not necessarily describe which stakeholders should be consulted or how they should be involved in the values formation process. For example, when organisations use visionary leadership to formulate strategy, leaders must have a sound understanding of their own values, those of the organisation and of the market, in order that they can make well-directed decisions. Whereas an organisation formulating a strategy between many antonymous subgroups, may choose to understand separate stakeholder group values and to align these when necessary to reach consensus. In an organisation with a clearly defined leader, the leadership role, will play a critical role in creating and maintaining an organisation's culture. From the outset, a founder will begin the cultural creation process in an organisation by recruiting, selecting and promoting who they think will most successfully deliver their vision. According to Schein (2004), leaders embed their values within a culture because people are guided by what leaders pay attention to, measure and control. More recent debates on transformational leadership and values- based management, stress the transfer of individual and organisational means, and ends values from leaders to employees to increase their understanding of task importance. As such leaders must ensure that their values are clear and congruent with their actions to build confidence and trust (Ciulla, 1999).

Organisations are institutions that are 'nested within societies' and influenced by national cultures and local communities (Sagiv and Schwartz, 2007). According to them, this may partly be because 'organisations must gain and maintain a minimal level of approval from society in order to function effectively' (p. 178). Since such approval is necessary in order to recruit, obtain resources and find markets. Further to this 'in the long run, organisations must be able to justify their activity as expressing or at least not contradicting the preferred values prevalent in their society' (Sagiv and Schwartz, 2007, p. 178). Other- wise, they face criticism, pressure to change, 
or even denial of resources. Consequently, negative press and constraints imposed on a business can be severely damaging to an organisation, so they must align and 'develop and evolve in ways that are compatible to some degree with the societal culture in which they are nested' (Sagiv and Schwartz, 2007, p. 178).

\section{Project values and stakeholder value management}

Values definition is rarely described in a project context, which is surprising given that it is this temporary environment that brings together organisations, disciplines and wider stakeholders with potentially divergent values systems and influences. There are however a number of construction specific project approaches that we will further discuss here. FUSION is a clientdeveloped, project team collaboration tool that has been promoted by the Strategic Forum for Construction (Thomas, 2000). It uses a behaviour-based questionnaire structured around six collaboration values (Fairness, Unity, Seamless, Initiative, Openness and No blame) as a means to enable a team to understand and measure good partnering practices. This tool, whilst promoting a highly effective structured discussion, focuses on partnering values, and so does not elicit the full array of values relevant to all stakeholders, processes and products and does not explicitly balance conflicting values. Other approaches, such as value management and architectural brief-taking see values expressed in the mix of requirements, objectives and functions (Kelly, 2007; Liu and Leung, 2002). However, people may find values difficult to express in a group-based environment (with strong minded individuals), where quick consensus is important and without concerted effort, structure and facilitation skill. This presents an opportunity to develop a structured and easily applied method for use within a project context.

\section{Individual values and motivation}

Some academics have grown cautious and sceptical of the importance of shared monolithic organisational values, reputing that they cannot fully explain or predict human action. Swindler (1986) saw the social action and motivation of individuals as complex, where peoples' perceptions shift and change to make decisions based on many conflicting individual and social factors. As such, corporate leaders cannot expect to drive an organisation by articulating abstract, sociological values statements alone, rather they must also be considerate of individuals' values and their alignment with organisational statements. Several empirical studies have shown that individual and organisational values alignment can positively affect employee satisfaction, work attitude, commitment, effectiveness and staff turnover (Meglino et al., 1989; O'Reilly et al., 1991; Posner et al., 1985). What is more, statements from senior executives of successful multi-national organisations such as Microsoft (Peat, 2003) and Levi Strauss (Haas and Howard, 1990), also provide evidence of the benefits of aligning individual and organisational values.

The empirical work of Posner and Schmidt (1993) is perhaps the most interesting in relation to the alignment of individual and organisational values. Following the research of Liedtka (1989), they sampled 1059 individuals and grouped them into four subgroups according to their own perception of the clarity and certainty with which they understood their individual and organisational values, and then correlated these results with work commitment and ethical attitudes. Those in the sample who were aware of both their individual and organisational values 
had the highest level of commitment and a positive attitude towards their work and ethical practices, whereas those who were unaware of individual and organisational values were less committed and had more negative attitudes. Interestingly, those who had an understanding of their individual values but did not understand the organisations values, had relatively high attitude and commitment to work, while those who were personally unsure of their individual values but under- stood those of their organisation were less positive and less committed to their work. According to Posner and Schmidt (1993), this may suggest that clarity about personal values is more important than an understanding of organisational values in improving attitudes and work commitment; also maybe suggesting that the values that motivate one person may not motivate another. For example, an individual who rates conformity values highly, may determinedly work towards a set of organisational values, and may restrain their own priorities. In contrast, an individual who rates self-direction values highly, may be more likely to make autonomous choices, and will be less likely to conform to values imposed on them. This suggests that individual commitment will be greater when an individual's values are aligned and collectively realised with those of their organisation.

Many authors would agree that organisations that express human values will provide employees with a broader and more motivating common purpose than those organisations that define strategic goals alone. For example, Sawhney (2002) believes organisations will motivate employees, satisfy customers and create committed partners by making 'higher purpose their compass, and values their anchor' (Paragraph 4). Similarly, Peat (2003) believes that shared organisational values will 'harness the emotions and spirit of every individual towards a common purpose' (p. 3), while Dolan and Garcia (2002) claim that employees will give their commitment and be inspired to take ownership of their work if they share a common purpose (minimising the need for time-consuming controls). What these examples emphasise is that organisations should think of organisational values as energizing, motivating, and inspiring concepts that people care passionately about rather than 'shoulds' on what to do or not to do; because when people value something they spur themselves on to greater achievements (Jaffe, 1998).

Given the complexity surrounding values and their application, it is unlikely that organisational priorities, defined as values statements alone, will be enough to inform day-to-day decision making. Individuals at all levels should have the understanding and skills to make value judgements and be conscious of their individual and organisational values, to help them build enthusiasm, commitment, and address mis- alignment and potential conflicts. The risk of not aligning individual and organisational values may be that employees find it hard to commit to those strategic organisational values exposed by senior man- agers, resulting in values not being enacted in practice and perceptions of 'empty', 'lofty' and 'hollow' organisational commitments. This according to Lencioni (2002) and Sawhney (2002) can do more harm than good and can lead to cynical and dispirited employees, alienated customers, and discredited management. Given the strength of these arguments, we recommend that individual and organisational values should be aligned, rather than imposed top down as a set of monolithic values by senior managers. 


\section{Applying values}

Values priorities are often tacitly held by individuals, which accounts for the popularity of predefined lists or taxonomies of values. What is more, people have a tendency to project their own values onto others, by assuming that everyone perceives the world in the same way, because it is language that helps and delimits the development of values. As such, it is often only by understanding our own values, that we can start to, without bias, recognise the values systems of others, and so it is important that everyone understands that peoples' diverse value judgements should be respected.

This article reviews the theoretical content and structure of a number of highly rational values identification methods that can be quickly used to confirm or deduce the values of large organisational samples, that is in contrast to the most applied methods today. Application methods within the construction industry, by-and-large, are applied informally and do not stress the significance of all individuals in delivering organisational values through their actions and behaviours day-to-day; rather they define the values statements of a core management team through brainstorming work- shops, which do not build organisation wide commitment and at best describe a simplistic view of organisation's high level priorities. What is important to remember here is that according to Baines (1998), 'much of the benefit of values ownership is achieved through truly participative processes' (p. 14), a view shared by McDonald and Gandz (1992), Jaffe (1998) and Sawhney (2002), and enacted within multi-national companies by Jaffe (1998), using 'value cards' as a starting point to initiate discussion. Some authors, however, contest that organisational values identification should be a 'feel good effort' to engage employees and build consensus, rather a way of imposing fundamental and strategically sound belief structures on a broad group of people (Lencioni, 2002, p. 116). We believe that individual values identification is both a personal and organisational process that allows staff to present their views and leaders to reconcile these with their own.

Values are deeply and often tacitly held beliefs. As such the sharing of individual responses must be pre- agreed by all participants and anonymity must be used when necessary to minimise surprise. It is important that employee expectations are communicated openly, and that resources and senior management commitment are provided. It is also important to pre-agree the personal and strategic mechanisms that will enable and measure the enactment of values in practice, for example employee- manager interfaces by way of personal review, Brown (1976), strategic committees, employee representative groups and customer market planning activities to align individual, organisational and market values.

\section{Values theory}

Our research has concentrated on the need for construction businesses, policy makers and other stakeholders to develop a better understanding of their values and has sought an appropriate method of values identification with a sound theoretical basis. Described here are some of the key authors in human values theory development.

\section{Historical and theoretical perspectives}

There is growing consensus regarding the most helpful means to conceptualise basic human values, but this has not always been the case, with many concepts needing disentangling 
(Hofstede, 1998). We outline here key contributors to the field of human values theory before focussing on that of Shalom Schwartz. Kluckhohn (1951) wrote: 'A value is a conception, explicit or implicit, distinctive of an individual or characteristic of a group, of the desirable, which influences the selection from available modes, means, and ends of action' (p. 395). This definition firmly attributed values as person-centred and established them as characteristics of both individuals and groups. Subsequently, Rokeach (1972) defined values as '...enduring belief[s] that a specific mode of conduct is personally or socially preferable to an opposite or converse mode of conduct or end-state of existence' (pp. 159-160). He recognised values as giving meaning to action, postulated their dynamic trade-off structure and described them as relatively enduring over time. More recently, Schwartz $(1987,1992,1994 a, 2005)$ has gained widespread agreement on five features of values as:

1. beliefs, cognitive structures that become infused with feelings;

2. desired goals with motivational ends that people (e.g. organisational leaders, policy-makers, individual persons) strive to attain;

3. transcending specific actions and situations as socially desirable goals that people think they ought to realise;

4. standards or criteria used to judge most things of importance, including the selection or evaluation of objects, actions, policies, people and events as either good or bad; and

5. ordered by relative importance and so form a system of value priorities that characterise cultures and individuals.

Values have been confused with many different, but similar concepts and so here we try to differentiate between them. Unlike attitudes, values are abstract humanly held notions that are not related to any particular object. According to Rokeach (1973), values hold a higher place in people's internal evaluative hierarchy than attitudes and as such values-based behaviour, rather than actions driven by personality traits, has more cognitive control. In a similar way to how values frame value judgments, one or many values may frame an individual's attitude. Values are usually desirable or positive statements, '...otherwise we would speak of disvalues', in contrast to attitudes, which can be both positive and negatively expressed (Rescher, 1969, p. 5).

The breadth of values understanding is of particular relevance in enacting business ethics and corporate social responsibility. Values provide a broad framing structure that helps us to understand particular choices in a wider context of concerns that will shape ethical decision making (Carroll, 1996; Guth and Tagiuri, 1965). This same view is well illustrated by Hitlin and Piliavin (2004), who see values forming an internal moral compass.

Values are learned by individuals through socialisation according to the specific moral and cultural paradigms within a social group. Norms also play a key role in the socialisation process, however, they capture an 'ought' sense, whereas values capture a personal or cultural ideal (Hofstede, 1998). Individual values are acquired in a persons '...early youth, mainly in family and in the neighbourhood, and later at school. By the age of 10, most of the child's values have been programmed into his or her mind' (Hofstede, 2001, p. 394). However, a person values priorities may change throughout their working lives through experience, knowledge and skills growth. 
Every individual or group will have values that are partly unique and partly shared, and as such universal values are those that are shared by all people, across all nations, ages, backgrounds and religions, and hence existing and persisting in an 'objective sense' (Haller, 2002, p. 141). According to Schwartz (2005), universality in values is a result of three requirements of the human condition: the needs of individuals as biological organisms, the requisites of coordinated social interaction, and survival and welfare needs of groups. The major differences between values and needs is that values are always motivational, unlike needs that are only motivational when they are unsatisfied (Maslow, 1962).

The link between values and behaviour remains unclear; however, values seem to act as guidelines that direct value congruent behaviour (Bardi and Schwartz, 2003; Desjardins, 2002; Hitlin and Piliavin, 2004; Jaffe, 1998; Jones and Pollitt, 1999; Peat, 2003; Sawhney, 2002; Schwartz, 2005; Smith et al., 2002). What is interesting is that we can in part understand both values and behaviours using the same universal values structure. This has been demonstrated empirically by Bardi and Schwartz (2003), who believes that people behave according to values because of a need for consistency, to help in relationships or because value-consistent action is rewarding and helps people get what they want. As such the relationship between behaviours and values exhibits a similar structure to the motivational continuum in Schwartz's values theory, presented later in this article.

In 2002, the European Social Survey (City University, 2007) was commissioned to explain the interactions among European attitudes, beliefs and behaviour patterns, and how these change over time. This survey is being administered internationally under the three themes of: people's value and ideological orientations, people's cultural/national orientations and the underlying social structure of society. Schwartz himself is one of the international academic specialist within the human values field to be commissioned to investigate people's world views, including their religiosity, their socio-political values and their moral standpoints. For this, he derived 21 basic human values items and a scale from the well-grounded theory, later applied in this article. The data from the European Social Survey (ESS) will no doubt provide highly valuable information along with the European (and World) Values Surveys and the International Social Survey to help understand the similarities and differences between cultures and their cohesion.

\section{Universal human values content and structure}

This article investigates the role of identifying universal values, as a means of promoting a dialogue of values within the construction industry. However, in taking this rational ontological position, we have excluded the use of more subjective and qualitative methods that can collect unique values using, for example elicitation techniques. In doing so, our assumption is that different cultures and individuals, while sharing a universal language of values, will prioritise them differently, depending on their unique experiences.

There are significant theoretical and practical advantages to identifying a limited set of universal values. Rokeach (1973) was one of the first to use values surveys derived from a theoretical perspective. He selected 36 values largely on an intuitive basis informed by literature and interviews. From this, he postulated that values could be classified according to specific socialisation groups such as family, religion and politics, forming interdependent types that were 
in opposition to one another: moral versus competence and personal versus social. Schwartz (1987) and Schwartz and Bilsky (1990) took a more structured approach by suggesting an underlying tentative theory based on universal requirements of human nature and interest (individualistic vs. collectivist) that encompassed 11 motivational goals based on 56 specific values. According to Schwartz (1992), the 56 values were a combination of 21 values items identified by Rokeach (1973), as well as Braithwaite and Law (1985), Chinese Culture Connection (1987), Hofstede (1980), Levy and Guttman (1974), and Munro (1985). The 56 values were judged to have a clear motivational goal; however, in some cases, values had multiple goals, for example intelligent and self-respect. According to Schwartz and Boehnke (2004) and Schwartz (2005), this survey instrument was validated, through use, by some 64,000 people, across 67 countries, from highly diverse geographic, cultural, linguistic and religious backgrounds. Schwartz then used confirmatory factor analysis, with just under 11,000 people over 27 countries, to revalidate his theory that was previously devised using similarity structure analysis (Schwartz 1987), and more recently with more widely available factor analysis techniques.

Schwartz's model and fundamental motivational continuum are the most advanced values theory to date and can help individuals and organisations move beyond studying independent and singular values, to think about values systems and the dynamic interrelated structure of values. As we will see, other authors have tried to identify and classify values, by intuitively ordered values into groups to add efficiency to sorting and data analysis. However, these categorisations may be less rigorous than those defined by Schwartz empirically using Similarity Structure Analysis, a procedure that maps values items as points in a multi- dimensional space and where the distance between values items is their degree of interrelatedness (Schwartz, 2005).

It is important to note that the same basic dynamic values structure active in the individual- level values model is also active at the cultural and institutional level. According to Schwartz (1994b, 1999), this individual and cultural congruence is because of the conflict or hypocrisy that would arise were institutions to emphasise and promote competing values simultaneously. He goes on to say that whatever the level, values are conceptually related, first because the social priorities of a culture will emerge from the psychological dynamics inherent in human nature and in universal aspects of social interaction. Second, individuals are socialised into an organisation, internalising the values that will pro- mote common interests and conform to organisational norms. Third, cultural value priorities help to determine whether conflict or compatibility is experienced.

According to Schwartz (2005), values, approximately speaking, fall into one of 10 universal values categories within a quasi-circumflex system. This motivational continuum has 'fuzzy' lines of segregation, where adjacent values are congruent because they share an underlying need or motivational goal, while those which are opposite in the circle conflict, because their underlying motivations are opposed. Figure 1 is an adaptation of Schwartz and Boehnke's (2004) own model, which pictures the '...total pattern of relations of conflict and compatibility among values priorities' (p. 231). Theoretically, Schwartz's model locates tradition outside conformity in a single segment, because they share the same broad motivational goal (e.g. 'subordinating self in 


\section{FIGURE 1 ABOUT HERE}

favour of socially imposed expectations', p. 235). However, Schwartz and Boehnke (2004) themselves explains that it is hard on empirical grounds to choose whether they should be defined as one or two categories, As such, we have pictured Tradition and Conformity side-byside to simplify data presentation and analysis.

The most basic and well-supported values inter- relationship is between individual and collective interests, where the attainment of values that serve individual interests are by their nature opposed to those that serve collective interests (Hofstede, 2001; Schwartz, 1994a). The next level segments into four, with two higher-order bipolar value dimensions, self-transcendence versus self-enhancement and openness to change versus conservation. At the next level are the 10 motivational types, which are populated with the 56 values items. According to Schwartz, this fundamental model can be partitioned at any level into as many or as few categories as required to describe more simply the circular motivational continuum. Schwartz and Boehnke's (2004) own model is segmented into the four higher-order values, however, we in Figure 1, use further categorisations of adjacent motivational types, as defined by Schwartz (1992) and further described in Table I. This interrelationship between values forms a competing values system structure that is a dynamic predictor of value conflict and congruence within individuals and groups.

\section{TABLE 1 ABOUT HERE}

\section{Comparisons of values taxonomies}

Schwartz (1992) comments that the comprehensiveness of any instrument is a basic methodological problem made more important, because without it the study of values correlation and relative importance will be less robust. Table II compares, against the SVS, the comprehensiveness of four well-known values lists that are practical and relevant to occupational work situations. These include: Rokeach (1973), whose list was the principle source for Schwartz; Jaffe and Scott (2004), who developed a values instrument, and card sorting method to identify individual and team values as a means of creating organisational values statements congruent with individuals; McDonald and Gandz (1992), whose list is based, in part, from mapping Allport (1961), England (1967) and Rokeach (1973), and aimed at Managers and Human Resource professionals to discuss, agree and manage shared values as they integrate with business strategies; and lastly Hofstede (2001) and Hofstede et al. (1993), whose VSM questionnaire is widely used in business management, and combines items that elicit the importance of both work values and practices. A number of authors have been omitted due to the non avail- ability of their instruments; however, Braithwaite and Scott (1991) provides a broad review of values identification methods, but not Schwartz or the full content of these methods. 
Authors of particular significance from Braithwaite and Scott (1991) are: Inglehart (1971) who's conceptualisation, according to Braithwaite and Scott (1991) is based on Maslow's (1962) theory of human needs and Gordon (1960) survey of Personal and Interpersonal Values, that further operationalises the distinction between individual (self-oriented values) and collective (grouporiented values). The primary impetus be- hind the comparison in this article is to identify a suitable language of values which could be used by the range of stakeholders, who might be involved in a construction project, from novice clients to construction professionals. Table II shows in bold text, values items from alternative lists that are directly equivalent to those in Schwartz and Boehnke (2004), in plain text indirect and more specific alternative values descriptions. Italic text shows more specific work situated values and a ' $X$ ' is where a list has no alternative value.

\section{TABLE II ABOUT HERE}

This investigation shows the Schwartz and Boehnke (2004) 56 values item definition to be the most complete values definition, followed by Jaffe and Scott (2004) covering $54 \%$, Rokeach (1973) 52\%, Hofstede et al. (1993) and Hofstede (2001) 21\%, which has 23 work-related items that may account for the low coverage, and McDonald and Gandz (1992) 20\%.

Mapping value criteria at both the category level and individual value item level, illustrated that while some relationships were intuitively aligned, categorisations in the three alternative lists fell across different Schwartz and Boehnke (2004) categories. As such, Schwartz's empirically tested universal values structure may illustrate the subjectivity of categorisation in these alternative lists.

Given that values are scored relative to one another, the breadth of values is highly important during their measurement. Some authors have excluded whole categories, for example only half of the authors sam- pled have identified values relating to the Tradition category. Schwartz (1992) asserts that the 10 motivational goals are exhaustive of all the main types recognised in different cultures because 'it is possible to classify virtually all the items found in lists of specific values from different cultures... into one of these 10 motivational types of values' (pp. 22-23). What this investigation may show is that the work-related taxonomies such as Jaffe and Scott (2004), McDonald and Gandz (1992), Hofstede et al. (1993) and Hofstede (2001) may be deliberately narrower in their content; for example they tend to include fewer ethical values (e.g. Protecting the environment, Social justice, Beauty, Security) and fewer values that may be seen by users to be inappropriate within a work context (e.g. Preserving public image, Pleasure, Enjoyment, Self- indulgence, Excitement, Daring, Independence, Choosing own goals, Curious, Inner harmony, Spirituality, Belonging and Privacy). However, given the importance of ethical decision making and employee satisfaction in today's working environment, we favour the open use of a broader values list like Schwartz and Boehnke (2004), as opposed to other narrow and somewhat imposing values list. 
There were several items across the lists, that did not have a direct Schwartz and Boehnke (2004) values equivalence, including: seven work items (Diplomacy, Communication, Community, Appearance, Courageous, Challenge and Integrity) from Jaffe and Scott (2004); three work values (Adaptability, Economy and Openness) from McDonald and Gandz (1992); Courageous and Salvation from Rokeach (1973); and nine work values (Individual vs. group decision making, Efficiency of department, Work vs. family and leisure time, Fringe benefits, Physical working conditions, Living in a desirable area, Man- agers and employees help each other, Managers consult with employees and working relationship with boss) from McDonald and Gandz (1992).

These values are more context specific descriptions of attitudes that can be classified into or across the 10 motivational types, as practical means of achieving any one of a number of the values ends in Schwartz and Boehnke (2004). This shows that the SVS does not need amending; however, during application, more specific work or life values may, and should, be elicited and universally classified according to their type.

The above analysis has been undertaken at the level of the individual values items and shows the Schwartz and Boehnke (2004) list to be the most comprehensive. Schwartz's list has the advantage of a neutral language and perspective, which would be helpful when dealing with a range of stakeholders, including those without business interests. It is also of interest to make a comparison, where possible at the higher level of value categories or dimensions (which is the focus of Schwartz's work). It was Rokeach (1973), who first proposed that a higher level of a circumplex nature might exist, but his dimensions (from which the categories in Table II have been inferred) were relatively immature and untested. Similarly, those of Jaffe and Scott (2004), whilst presenting an intuitive grouping of lower level items, have little correspondence and less theoretical basis.

\section{Case studies to test the new approach}

This section presents an approach, which can help individuals to understand their personal interests, motivations and values in the context of their organisation. It also allows the definition of values statements as a means of communicating an organisation's mission and a starting point from which to define and measure supporting behaviours. A description of the adaptation of the Schwartz values survey can be found in the appendix.

\section{Data collection}

The approach to understanding values was trialled in three studies with the adapted SVS instrument. Eighty-four individuals from six industrial research partners volunteered to participate. Each individual participant used a questionnaire to comparatively rate the importance of 56 values 'as a guiding principle in my working life' on a 9-point scale with anchors of -1 ('opposed to my values') and 7 ('of supreme importance'). This individual questionnaire measures people's personal values priorities, not the approved norms of groups, where according to Schwartz (1992) the average individual values profile is 'one way to characterise cultural value priorities'.

Study A aimed to identify a construction partner- ing consultants organisational values priorities; study $B$ challenged the scope of values statements from five organisations, whilst study $C$ investigated the alignment of values within and among these five organisations. In study A, all 14 
employees responses were aggregated and averaged in a collective organisational values plot to reveal alignment and misalignment within the group, where according to Schwartz the average reflects the values of the group while 'individual variations around this average reflects unique personality and experience'. Study B was a simple subjective investigation of the breadth of each of the five organisations values statements. Study $C$ used survey data from 70 individuals from across five organisations, these included responses from: (QS) a cost consultancy firm, $n=18$; (Arch) an architectural practice, $n=17$; (Eng) a multi-disciplinary engineering organisation, $n=16$; (Value) a value management consultancy, $n=10$; and (Ops) a building maintenance and operations company, $\mathrm{n}=9$. In order to trial the application of the method, centred individuals' values data from study $\mathrm{C}$ was aggregated into groups to investigate organisational priorities and identify statistically significant differences across organisations, where averages and standard deviations were used to measure the importance and alignment and a t-test was used to measure organisational values differences. Age variability is unlikely to have a significant effect when comparing individual and organisational values priorities, as the average age within each organisational sample is relatively similar: QS $=38$ years, Arch $=40$ years, Eng $=38$ years, Value = 34 years, Ops $=36$ years.

\section{Study A: identifying an organisations values priorities}

Figure 2 compares the average of two analysis groups (a director group and the whole organisation group). High and low priority values were identified by the organisations choosing thresholds of 1 and -1 , respectively. Profiles given to each individual were also compared against the organisational average, to help them understand their own values priorities against those shared by the organisation.

Highly important values to the group were: 'Healthy', 'Honest', 'Successful', 'Enjoying work', 'Loyal', 'Security of friends and family' and 'Learn- ing', whilst the lowest importance values were: 'Social power', 'Respect for tradition', 'Accepting my portion in life', 'Spirituality in work', 'Unity with nature' and 'Moderate'.

The participants agreed that the adapted SVS questionnaire provoked the relative importance of values and helped ensure that the breadth of values concepts was considered. Individuals found that the comparison of their personal profile with the average, illustrated their degree of alignment with the organisation, including where they differed significantly. The directors, who had previously undertaken a brainstorming exercise to define organisational values at a management away day, said they preferred the SVS approach because it engaged all the staff in a structured way, and allowed individual values to be compared and aggregated. For them it was a catalyst for an open dialogue, which helped individuals gain commitment to a set of shared organisational values. This catalytic effect is one of the benefits of using a universal values language and visualisation method, unlike most alternative methods that may have less underlying theory to inform discussion.

FIGURE 2 ABOUT HERE 


\section{Study B: scope of existing organisational values}

We mapped the values statements (or their equivalent) of five businesses against Schwartz's 10 universal values categories (Table III). This test, while crude in that the statements were subjectively assigned to motivational types by the authors, demonstrated that some statements are limited in breadth, being narrowly defined around achievement and other- oriented goals. This may indicate limitations or bias in the methods used to create them within each organisation, the pervasiveness of the construction industry's current emphasis on principles such as collaboration and performance or a narrow focus on strategic values rather than a broader set of ethical stakeholder perspectives. In a bigger empirical study Webley (1999) reviewed the organisational values within many UK businesses and discovered that there was no clear language to define values and that the most commonly espoused values such as: 'people', 'competitiveness', 'customers', 'quality' and 'productivity' were not values at all, rather strategic goals. This supports the need for a new language of values and methods that can help individuals, business leaders and policy makers to identify priorities values that are relative to one another.

\section{TABLE III ABOUT HERE}

\section{Study C: alignment of values within and between organisations}

Table IV shows the average centred values priority within and among organisations. When using an arbitrary threshold for cross-organisational comparison, we can observe differences in values priorities (later this same data are statistically compared using a t-test). When looking at the average across all organisations, the top seven centred values (judged to be most important) are: 'Self-respect' (1.49), 'Heal- thy' (1.41), 'Honest' (1.35), 'Capable' (1.27), 'Meaning in work' (1.25), 'Security of friends and family' (1.24) and 'Responsible' (1.22). The least highly prioritised centred values are: 'Social power' (-2.97), 'Spirituality in work' (-2.61), 'Accepting my portion in life' (-2.48), 'Respect for tradition' (-2.04), 'Unity with nature' (-1.85), 'Moderate' (-1.43) and 'Humble' (-1.31). Four of these least highly prioritised centred values are from the 'tradition' category, which may suggest that it is the least important category to the sampled organisation.

Table V shows the standard deviation between individuals' centred values priorities within organisations. We can observe that some organisations more frequently have aligned values (above an arbitrary 1.0 threshold); for example Ops has 18 highly aligned values, while QS, Value and Arch have 7,7 and 9 aligned values. This could indicate different cultural paradigms and management approaches for example QS, Value and Arch could have decentralised and personcentred cultures, while Ops may be a strong leadership-centred organisation with a clearly understood ethos and enrolment process. Across organisations, the most consistently aligned values are 'Responsible' (0.83), 'Successful' (0.86), 'Capable' (0.89), 'Enjoying work' (0.90), 'Helpful' (0.91), 'Honest' (0.97), 'Loyal' (0.98). The most misaligned values are: 'Accepting my portion in life' (1.89), 'Social power' (1.83), 'Pleasure' (1.77), 'Preserving public image' (1.76), 'Humble' (1.76), 'Moderate' (1.72) and 'Honouring older more experienced others' (1.72). What is 
perhaps most interesting, particularly with regards to building strong multi-organisational project cultures or understanding uncertainty between project participants, is to observe values that are both strongly aligned and strongly misaligned by different organisations, for example: 'Social Justice' (aligned within Ops (0.93), while misaligned within Value (1.70); 'Broadminded' (aligned within Ops (0.92) and Arch (0.99), however, misaligned within Value (1.74); 'Respect for tradition' (aligned within Ops (0.83), however, misaligned within Value (1.81) and Arch (1.72) and Reciprocation of favours (aligned within Ops, however, misaligned within Eng).

Table VI shows that individuals are more likely to judge values as very important (48.6\%) than not important (8.1\%), with $43.2 \%$ judging them mod- erately important. The frequency analysis in Table VI supports the average and standard deviation in Tables IV and V.

\section{TABLE IV ABOUT HERE}

\section{TABLE V ABOUT HERE}

TABLE VI ABOUT HERE

\section{TABLE VII ABOUT HERE}

An independent-sample t-test was conducted to measure the equality of means between organisations (at a 0.05 significance level) to determine whether the values priorities of individuals in the five organisations are significantly different. The test results contained in Table VII, two-tail hypothesis was that there would be significantly different values priori- ties among organisations. Table VII contains the statistical differences among organisations.

This analysis provided some interesting results when looking at the organisational values priorities and role of specific organisations. For example (Arch) the architectural practice, subscribes more highly to values such as 'Aesthetics', 'Protecting the environment', 'Spirituality in work' and 'Creativity' than any other; while (Ops) the building maintenance/operation company, places greater emphasis on values such as 'Helpful', 'Honouring older more experienced others', 'Clean' and 'Choosing own goals'. These findings, while providing some insight to the specific values of these occupations, require further empirical work. It starts to reveal the extent of differences among organisations that can be found using a universal values measurement technique (e.g. 22 out of 56 values items were significant differentiators across these five organisations). It also showed that there was statistical misalignment between (QS) and (Arch) on 'Aesthetics' and 'Protecting the environment', between (Arch) and (Ops) on 'Clean', between (Eng) and (Arch) on 
'Creativity' and between (Value) and (Ops) on Helpful, and that there was statistical alignment between (Arch) and (Eng) on 'Protecting the environment'. This may show that such organisations have more similarities than differences when using universal values, and hence demonstrate the importance of using grounded and unstructured values elicitation methods along side universal techniques, as well as the extension to consider organisation-specific behaviours.

\section{Conclusion}

The growing number of government and industry measures of social value and quality make it clear that both public and private sector construction clients are calling for the demonstration of performance that goes beyond time, cost and technical quality. These demands suggest the need for tools to facilitate a dialogue of value and human values to help define people's priorities and integrate them into construction processes and products. Values theory and practice has been presented to support this need. The results of three case studies demonstrate the unique application of this existing approach within construction to create individual and organisational profiles of values priorities that directly reflect reality.

Further research is needed to understand how values definition processes can help individuals understand values trade-offs, reach consensus, avoid conflict, make good value judgements in day-to-day situations, become more productive and understand value-related attitudes.

\section{Acknowledgements}

This research was undertaken by the Managing Value Delivery in Design study at Loughborough University and is part of the outcome of VALiD (www.valueindesign.com). The VALiD approach to values delivery and value demonstration is currently being de- ployed by construction organisations within both the private and public sectors, and experiences are expected to provide further insights and developments. The work was conducted in the Innovative Manufacturing and Construction Research Centre (IMCRC) and was funded by the EPSRC and the DTI under grant numbers GR/R64490/01 and 39/12/16 cc2323 respectively. The authors acknowledge the extensive support of the Department of Civil and Building Engineering at Loughborough University, AMEC, Arup, BAA, Be, Broadgate Estates Limited, CIBSE; Davis Langdon LLP; Sheppard Robson, RIBA and the RICS Foundation.

\section{Appendix}

The approach to understanding values presented in this article is based on that of Schwartz (1992) and Schwartz and Boehnke (2004), which stands apart from all other values surveys because, as we have previously explained, it provides a well-validated theory of human values, which is structured into 10 basic motivational orientations. As we have seen, from its comparison to alternative lists, Schwartz provides the most complete list available that enables values to be comparatively scored relative to one another, to 'measure people's value priorities' (Schwartz, 1992).

In order to apply this questionnaire within a construction context, some amendments have been made to the 56 values questions and the analysis method, while still insuring its conceptual completeness. The language of 26 Schwartz values have been slightly changed to make them more appropriate for a construction audience by relating them to work rather than personal life. 
Two data sources were mapped to the Schwartz questionnaire to inform this adaptation and understand the multi-level, multi-concept nature of these other instruments. These were a construction industry set of 130 Value Drivers, who had been classified into 14 categories by CE (2003) and the Hofstede Value Survey Module (VSM) (Hofstede, 2001; Hofstede et al., 1993). As a result, there have been significant language changes to seven values items, where four of these were to the values statement itself, rather than its defining description: 'Wisdom' (adapted to 'Wise in issues of ethics'), 'Social justice', 'True friendship', 'Obedient (adapted to 'Dutiful and professional'), 'National security' (adapted to 'Social security'), 'A world of beauty' (adapted to 'Aesthetic beauty') and 'Daring'. In order to de-emphasis values largely irrelevant to work, 'Selfindulgence' was incorporated into 'Pleasure', while 'Mature love' has been incorporated into 'True friendship'. Learning' has been added and incorporated into the Achievement values category.

In order to understand how intuitive the Schwartz category labels were for the construction industry, 10 construction professionals in three subgroups reviewed the adapted SVS that had been categorised into the 10 Schwartz motivational types, however, not named. These professionals then derived their own category name by looking at the values items that made up a grouping. This investigation demonstrated that the terminology used by Schwartz and the groups' own categories were very similar in approximately $40 \%$ of the cases and that nine out of the 10 category labels would be readily understood by construction industry practitioners, however, it was agreed that Benevolence should be simplified to Others Oriented.

\section{References}

Allport, G. W.: 1961, Pattern and Growth in Personality (Holt, Rinehart and Winston, New York).

Bailey, A. and G. Johnson: 1992, 'How Strategies Develop in Organisations', in D Faulkner and G Johnson (eds.), The Challenge of Strategic Management (Kogan Page Ltd., London), pp. $147-175$.

Baines, A.: 1998, 'Creating a Culture of Ownership', Work Study 47(1), 14-16. doi: 10.1108/004380298 10198458.

Bardi, A. and S. H. Schwartz: 2003, 'Values and Behaviours: Strength and Structure of Relations', Personality and Social Psychology Bulletin 29(10), 1207-1220. doi: 10.1177/0146167203254602.

Braithwaite, V. A. and H. G. Law: 1985, 'Structure of Human Values: Testing the Adequacy of the Rokeach Value Survey', Journal of Personality and Social Psychology 49, 250-263. doi: 10.1037/0022-3514.49.1.250

Braithwaite, V. A. and W. A. Scott: 1991, Values. Measures of Personality and Social Psychological Attitudes (Measures of Social Psychological Attitudes). (J. P. Robinson. US, Academic Press Inc), pp. 661-753.

Brown, M. A.: 1976, 'Values - A Necessary but Neglected Ingredient of Motivation on the Job', Academy of Management Review 1(1), 15-23. doi:10.2307/257721.

CABE: 2002, The Value of Good Design: How Buildings and Spaces Create Economic and Social Value. www.cabe.org.uk. London, Commission for Architecture and the Built Environment. 
CABE: 2003, Creating Excellent Buildings: A Guide for Clients. www.cabe.org.uk. London, Commission for Architecture and the Built Environment.

CABE: 2004, in T. Mason, B. V. Bruggen and P. Stewart (eds.), Design Reviewed: Urban Housing. www.cabe. org.uk, London, Commission for Architecture and the Built Environment.

CABE: 2005, Physical Capital: How Great Places Boost Public Capital. www.cabe.org.uk, London, Commission for Architecture and the Built Environment.

Carroll, A. B.: 1996, Business and Society: Ethics and Stakeholder Management, 3rd Edition (South-Western College Publishing, Cincinnati).

CE: 2003, Benchmarking Value Drivers. Buildings \& Estates Forum, Be Inspired, Constructing Excellence, Building \& Estates Forum: p. 18.

Chinese Culture Connection: 1987, 'Chinese Values and the Search for Culture-Free Dimensions of Culture', Journal of Cross-Cultural Psychology 18, 143-164. doi:

10.1177/0022002187018002002.

City University: 2007, 'European Social Survey (the ESS)', from http:// www.europeansocialsurvey.org/.

Ciulla, J. B.: 1999, 'The Importance of Leadership in Shaping Business Values', Long Range Planning 32(2), 166-172. doi:10.1016/S0024-6301(98)00145-9.

Desjardins, N. M.: 2002, A Case Study in Organizational Value Communication: Understanding Value/Behaviour Relationship. Central Connecticut State University. Master's Thesis, Department of Communication.

Dolan, S. L. and S. Garcia: 2002, 'Managing by Values: Cultural Redesign for Strategic Organizational Change at the Dawn of the Twenty-First Century', The Journal of Management Development 21(2), 101-117.

Egan, J.: 2002, Accelerating Change - A Report by the Strategic Forum for Construction. Rethinking Construction. S. F. f. Construction, London.

Gordon, L.: 1960, Survey of Interpersonal Values (Science Research Associates, Chicago).

Guth, W. D. and R. Tagiuri: 1965, 'Personal Values and Corporate Strategy', Harvard Business Review (Sept-Oct), 123-132.

Haas, R. and R. Howard: 1990, 'Values Make the Company: An Interview with Robert Haas', Harvard Business Review 90(5), 133-146.

Haller, M.: 2002, 'Theory and Method in the Comparative Study of Values', European Sociological Review 18(2), 139-158. doi:10.1093/esr/18.2.139.

Handy, C.: 1993, Understanding Organizations (Penguin, Harmondsworth, Middlesex).

Hitlin, S. and J. A. Piliavin: 2004, 'Values: Reviving a Dormant Concept', Annual Review of Sociology 30, 359- 393. doi:10.1146/annurev.soc.30.012703.110640.

Hofstede, G.: 1980, Culture's Consequences: International Differences in Work-Related Values (Sage, Beverly Hills, CA). 
Hofstede, G.: 1998, 'Attitudes, Values and Organisational Cultures: Disentangling the Concepts', Organization Studies 19(3), 477-492. doi:10.1177/017084069801900305.

Hofstede, G.: 2001, Cultures Consequences, 2nd Edition (Sage Publications, Inc, London).

Hofstede, G. and M. H. Bond, et al.: 1993, 'Individual Perceptions of Organizational Cultures: A Methodo- logical treatise on Levels of Analysis', Organization Studies 14(4), 483-503. doi: 10.1177/017084069301400402.

Inglehart, R.: 1971, The Silent Revolution (Princeton University Press, Princeton, NJ).

Jaffe, D. T.: 1998, 'How to Link Personal Values with Team Value', Training \& Development 52(3), $24-30$

Jaffe, D. T. and C. D. Scott: 2004, 'Real Learning Values Cards', This Tool Forms Part of the Toolset of Change Works Global. Retrieved January, 2004.

Jones, I. W. and M. G. Pollitt: 1999, 'Putting Values into Action: Lessons from Best Practice', Long Range Planning 32(2), 162-165. doi:10.1016/S0024-6301(99)00017-5.

Kelly, J.: 2007, 'Making Client Values Explicit in Value Management Workshops', Construction Management and Economics 25, 435-442. doi:10.1080/01446190601071839.

Kluckhohn, C.: 1951, The Study of Culture. D. Lerner and H. D. Lasswell (Stanford University Press, Stanford, CA), pp. 86-101.

Kotter, J. and J. Heskett: 1992, Corporate Culture and Performance (Free Press, USA).

Lencioni, P. M.: 2002, 'Making Your Values Mean Something', Harvard Business Review (July), 113-117.

Levy, S. and L. Guttman: 1974, Values and Attitudes of Israeli High School Youth (Israel Institute of Applied Social Research, Jerusalem).

Liedtka, J. M.: 1989, 'Value Congruence: The Interplay of Individual Organizational Value Systems', Journal of Business Ethics 8, 805-815. doi:10.1007/BF0038 3780.

Liu, A. M. M. and M.-Y. Leung: 2002, 'Developing a Soft Value Management Model', International Journal of Project Management 20, 341-349. doi:10.1016/S0263- 7863(01)00023-0.

Maslow, A. H.: 1962, Towards a Psychology of Being (D. Van Nostrand Company, Princeton, New Jersey).

McDonald, M.: 1996, 'Strategic Marketing Planning: Theory, Practice and Research Agendas', Journal of Marketing Management 12, 5-27.

McDonald, M.: 2002, Marketing Plans (Butterworth Heinemann, Oxford).

McDonald, P. and J. Gandz: 1992, 'Identification of Values relevant to Business Research', Human Resource Management 30(2), 217-236. doi:10.1002/hrm.3930300205.

Meglino, B. and E. Ravlin, et al.: 1989, 'A Work Value Approach to Corporate Culture: A Field Test of the Value Congruence Process and Its Relationship to Individual Outcomes', The Journal of Applied Psychology 74(3), 424-432. doi:10.1037/0021-9010.74.3.424. 
Munro, D.: 1985, 'A Free-Format Values Inventory: Explorations with Zimbabwean Student Teachers', South African Journal of Psychology. Suid-Afrikaanse Tydskrif Vir Sielkunde 15, 33-41.

NAO: 2004a, Improving Public Services Through Better Construction. Report by the Comptroller and Auditor General, London.

NAO: 2004b, Getting Value for Money from Construction Projects Through Design: How Auditors Can Help (D. L. Everest, London).

OGC: 2003, Achieving Excellence in Construction: Procurement Guide 09: Design Quality (HM Treasury, Office of Government Commerce, London).

OGC and CABE: 2002, Improving Standards of Design in the Procurement of Public Buildings (Office of Government Commerce, CABE, London).

O'Reilly, C. III and J. Chatman, et al.: 1991, 'People and Organizational Culture: A Profile Comparison Approach to Assessing Person-Organisation Fit', Academy of Management Journal 34(3), 487-516. doi:10. 2307/256404.

Peat, R.: 2003, 'Values Drive Value University of Auckland', Business Review (Federal Reserve Bank of Philadelphia) 5, 1-11.

Peters, T. J. and R. H. J. Waterman: 1982, In Search of Excellence: Lessons from America's BestRun Companies (Harper \& Row, New York).

Posner, B. Z. and J. M. Kouzes, et al.: 1985, 'Shared Values Make a Difference: An Empirical Test of Corporate Culture', Human Resource Management 24(3), 293-309. doi:10.1002/hrm. 3930240305.

Posner, B. Z. and W. H. Schmidt: 1993, 'Values Congruence and Differences Between the Interplay of Personal and Organizational Value Systems', Journal of Business Ethics 12(5), 341348. doi:10.1007/BF00882023.

Rescher, N.: 1969, Introduction to Value Theory (University Press of America, New York).

Rokeach, M.: 1972, Beliefs, Attitudes and Values: A Theory of Organization and Change (JosseyBass, San Francisco).

Rokeach, M.: 1973, The Nature of Human Values (The Free Press, New York).

Sagiv, L. and S. H. Schwartz: 2007, 'Cultural Values in Organisations: Insights for Europe', European Journal of International Management 1(3), 176-190. doi:10.1504/ EJIM. 2007.014692.

Sawhney, M.: 2002, 'Create Value from Values', CIO Magazine Nov 15.

Saxon, R.: 2005, 'Be Valuable - A Guide to Creating Value in the Built Environment', Buildings \& Estates Forum, www.constructingexcellence.org.uk.

Schein, E. H.: 2004, Organizational Culture and Leadership (Jossey-Bass (Wiley Imprint), San Francisco). 
Schwartz, S. and W. Bilsky: 1990, 'Toward a Theory of the Universal Content and Structure of Values: Extensions and Cross-Cultural Replications', Journal of Personality and Social Psychology 58(5), 878. doi:10.1037/0022- 3514.58.5.878.

Schwartz, S. H.: 1987, 'Toward a Universal Psychological Structure of Human Values', Journal of Personality and Social Psychology 53(3), 550-562. doi:10.1037/0022- 3514.53.3.550.

Schwartz, S. H.: 1992, 'Universals in the Content and Structure of Values: Theoretical Advances and Empirical Tests in 20 Countries', Advances in Experimental Social Psychology 25, 165. doi:10.1016/S0065-2601(08)60281-6.

Schwartz, S. H.: 1994a, 'Are There Universal Aspects in the Structure and Content of Human Values', The Journal of Social Issues 50, 19-45.

Schwartz, S. H.: 1994b, 'Beyond Individualism/Collectivism: New Cultural Dimensions of Values', in U. Kim, H. C. Triandis, C. Kagitc ibasi, S.-C. Choi and G. Yoon (eds.), Individualism and Collectivism: Theory, Method and Application (Sage Publications, Thousand Oaks, CA), pp. $85-122$

Schwartz, S. H.: 1999, 'A Theory of Cultural Values and Some Implications for Work', Applied Psychology: An International Review 48(1), 23-47.

Schwartz, S. H.: 2005, 'Basic Human Values: Their Content and Structure Across Cultures', in A. Tamayo and J. B. Porto (eds.), Valores e comportamento nas organiza cõ es [Values and Behavior in Organizations]. Brazil. Vozes de Petró polis 21-55.

Schwartz, S. H. and K. Boehnke: 2004, 'Evaluating the Structure of Human Values with Confirmatory Factor Analysis', Journal of Research in Personality 38, 230-255. doi: 10.1016/S0092-6566(03)00069-2.

Smith, P. B. and M. F. Peterson, et al.: 2002, 'Cultural Values, Sources of Guidance, and their Relevance to Managerial Behaviour', Journal of Cross-Cultural Psychology 33(2), 188208. doi:10.1177/00220221020 33002005.

Swindler, A.: 1986, 'Culture in Action: Symbols and Strategies', American Sociological Review 51 (April), 273- 286. doi:10.2307/2095521.

Thomas, K.: 2000, FUSION Guide: A New Approach to Working, CWC, 2007.

Thomson, D. S. and S. A. Austin, et al.: 2003, 'Managing Value and Quality in Design', Building Research \& Information 31(5), 334-345.

Webley, S.: 1999, 'Sources of Corporate Values', Long Range Planning 32(2), 173-178. doi: 10.1016/S0024- 6301(98)00146-0.

Worpole, K.: 2000, The Value of Architecture: Design, Economy and the Architectural Imagination (RIBA, Longdon). 


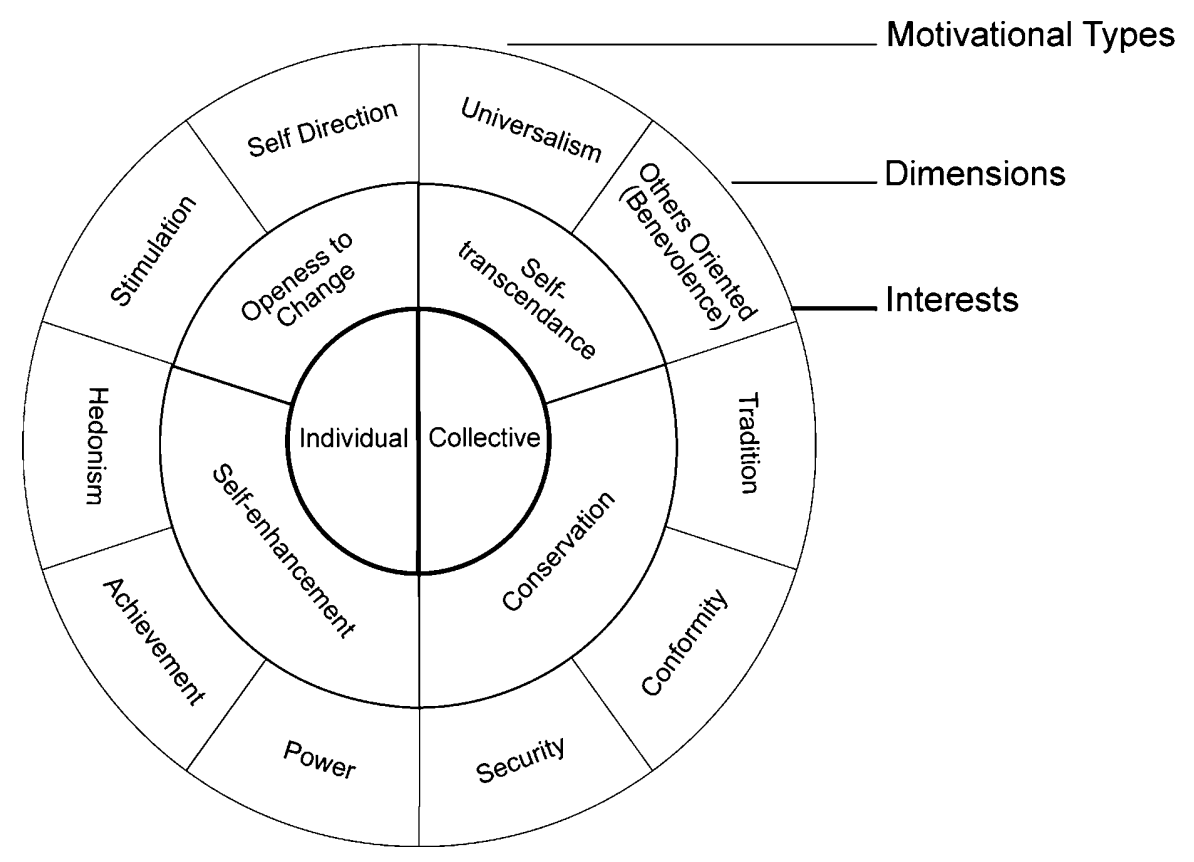

FIGURE 1: Theoretical Model of Relations Among 10 Motivational Types of Values, adapted from Schwartz and Boehnke (2004).

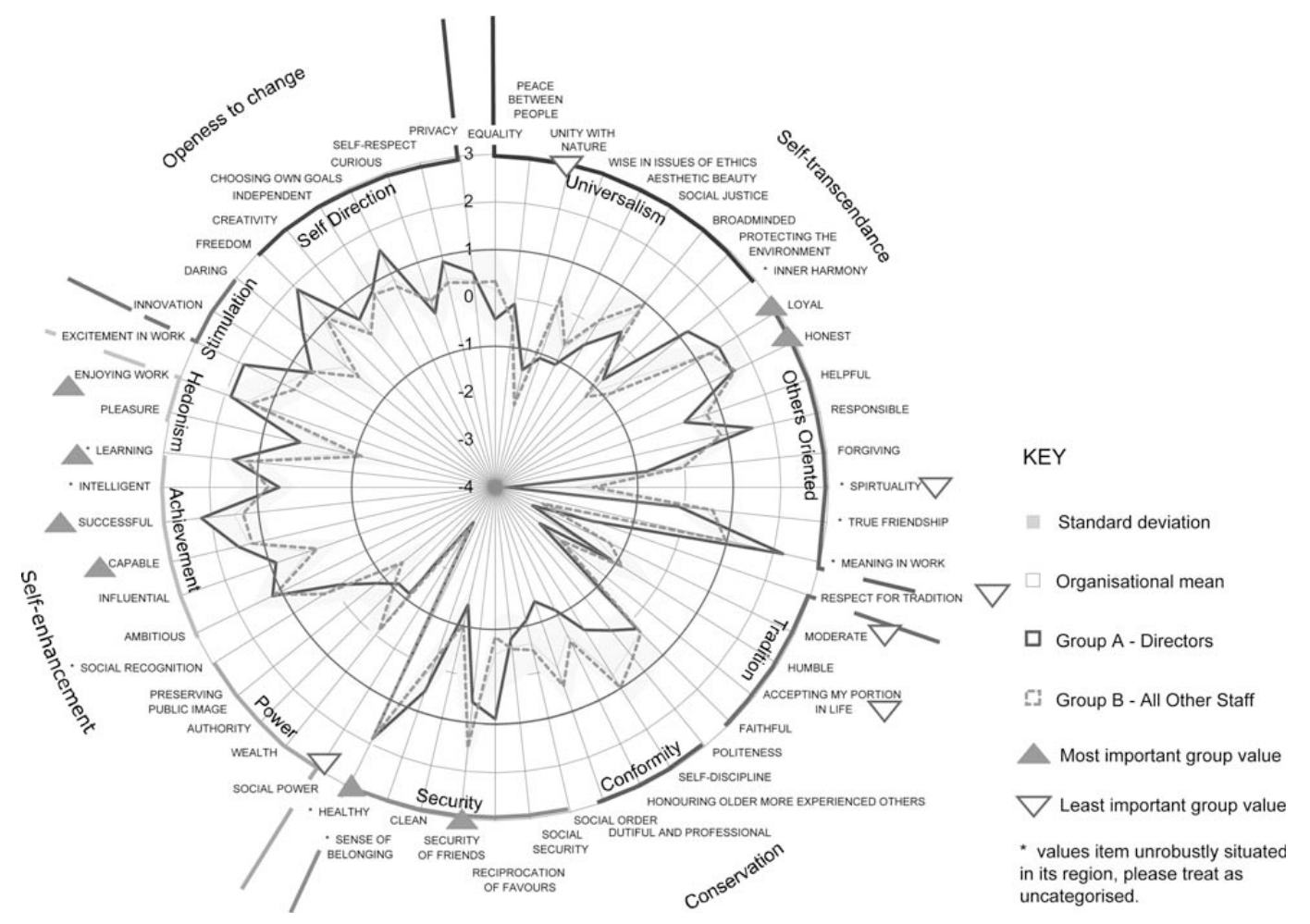

FIGURE 2: Director Values Priorities Compared to the Priorities of Other Staff 


\begin{tabular}{|c|c|c|c|c|c|}
\hline Motivational type & Goal & Description of motivational type & \multicolumn{3}{|c|}{$\begin{array}{c}\text { Compatibility (Motivational emphasis } \\
\text { of adjacent values) }\end{array}$} \\
\hline Universalism & $\begin{array}{l}\text { Welfare of all people } \\
\text { (understanding, } \\
\text { tolerance) }\end{array}$ & $\begin{array}{l}\text { Understanding, appreciation, tolerance, and } \\
\text { protection for the welfare of all people and } \\
\text { for nature. This contrasts with the others } \\
\text { oriented values in that Universalism values } \\
\text { are related to the wider society and world, } \\
\text { the scarcity of natural resources, and protec- } \\
\text { tion of the natural environment. People } \\
\text { holding these values see ethical and social } \\
\text { responsibility as very important issues, and as } \\
\text { such may consider their importance to be } \\
\text { objectively good or right }\end{array}$ & $\begin{array}{l}\text { Enhancement of } \\
\text { others and } \\
\text { transcendence of } \\
\text { selfish interests }\end{array}$ & \multicolumn{2}{|c|}{$\begin{array}{l}\text { Reliance upon one's own judgement } \\
\text { and comfort with diversity of existence }\end{array}$} \\
\hline $\begin{array}{l}\text { Others oriented } \\
\text { (benevolence) }\end{array}$ & $\begin{array}{l}\text { Welfare of personal } \\
\text { contacts }\end{array}$ & $\begin{array}{l}\text { Preserving and enhancing the welfare of } \\
\text { people within ones own group. They relate } \\
\text { to a persons requirement for smooth, aligned } \\
\text { and harmonious group functioning and from } \\
\text { their need for affiliation. People who see } \\
\text { these values as important are primarily } \\
\text { motivated by developing relationships, help- } \\
\text { ing and working with others, feeling part of a } \\
\text { team, and sharing experiences }\end{array}$ & & \multirow{2}{*}{\multicolumn{2}{|c|}{$\begin{array}{ll}\begin{array}{l}\text { Devotion to } \\
\text { one's group }\end{array} & \begin{array}{l}\text { Normative behaviour } \\
\text { that promotes close } \\
\text { relationships }\end{array}\end{array}$}} \\
\hline Tradition & $\begin{array}{l}\text { Respect, commitment } \\
\text { and acceptance of } \\
\text { customs }\end{array}$ & $\begin{array}{l}\text { Respect, commitment, subordination and } \\
\text { acceptance of the abstract customs and ideas } \\
\text { that a culture provides, such as religion. } \\
\text { Cultures everywhere develop practices, } \\
\text { symbols, ideas, and beliefs that represent their } \\
\text { shared experience, vision and mission. People } \\
\text { who hold these values focus on the enduring } \\
\text { qualities, which they understand and so are } \\
\text { comfortable with }\end{array}$ & $\begin{array}{l}\text { Subordination of self } \\
\text { in favour of socially } \\
\text { imposed expecta- } \\
\text { tions }\end{array}$ & & \\
\hline Conformity & $\begin{array}{l}\text { Avoiding upset or } \\
\text { harm to others }\end{array}$ & $\begin{array}{l}\text { Restraint of actions, inclinations, and im- } \\
\text { pulses likely to upset or harm others and } \\
\text { violate social expectations or norms. Con- } \\
\text { formity values emphasis people's self-restraint } \\
\text { in everyday interaction and their subordina- } \\
\text { tion to persons with whom they are in fre- } \\
\text { quent interaction (e.g. parents, teachers, } \\
\text { bosses) }\end{array}$ & & $\begin{array}{l}\text { Protection of } \\
\text { order and har- } \\
\text { mony in rela- } \\
\text { tions }\end{array}$ & $\begin{array}{l}\text { Normative behav- } \\
\text { iour that promotes } \\
\text { close relationships }{ }^{{ }^{1}}\end{array}$ \\
\hline Security & $\begin{array}{l}\text { Safety, harmony and } \\
\text { stability }\end{array}$ & $\begin{array}{l}\text { These values relate to the safety, harmony, } \\
\text { and stability of our society, group and self. } \\
\text { Some security values serve primary individual } \\
\text { interests (e.g. healthy), others primary wider } \\
\text { group interests (e.g. national security) }\end{array}$ & $\begin{array}{l}\text { Avoiding or over- } \\
\text { coming threats by } \\
\text { controlling relation- } \\
\text { ships and resources }\end{array}$ & & $\begin{array}{l}\text { Preserving existing } \\
\text { social arrangements } \\
\text { that give certainty to } \\
\text { life }^{\star 2}\end{array}$ \\
\hline Power & $\begin{array}{l}\text { Status, prestige and } \\
\text { control }\end{array}$ & $\begin{array}{l}\text { Social status and prestige, control or domi- } \\
\text { nance over people and resources. Power } \\
\text { values emphasise the attainment or preserva- } \\
\text { tion of a dominant position within a social } \\
\text { system }\end{array}$ & & \multirow{2}{*}{\multicolumn{2}{|c|}{ Social superiority and esteem }} \\
\hline Achievement & $\begin{array}{l}\text { Personal success and } \\
\text { competence }\end{array}$ & $\begin{array}{l}\text { These values represent the search for organ- } \\
\text { isational, professional and individual success } \\
\text { and the demonstration of competence } \\
\text { according to a social standard. They relate to } \\
\text { the successful generation of outcomes and use } \\
\text { of resources in order for individuals and } \\
\text { groups to progress and attain their goals }\end{array}$ & $\begin{array}{l}\text { Self-centred satisfac- } \\
\text { tion }\end{array}$ & & \\
\hline $\begin{array}{l}\text { Hedonism } \\
\text { (Enjoyment) }\end{array}$ & $\begin{array}{l}\text { Pleasure and sensuous } \\
\text { gratification }\end{array}$ & $\begin{array}{l}\text { Pleasure or the sensuous gratification of ones- } \\
\text { selves. Hedonism values are derived from } \\
\text { peoples' needs and expectation and the } \\
\text { pleasure associated with satisfying them }\end{array}$ & & \multirow{2}{*}{\multicolumn{2}{|c|}{ A desire for affectively pleasant arousal }} \\
\hline Stimulation & $\begin{array}{l}\text { Excitement, novelty } \\
\text { and challenge }\end{array}$ & $\begin{array}{l}\text { Excitement, novelty, and challenge in life. } \\
\text { Stimulation values are derived from the need } \\
\text { for variety and stimulation through our par- } \\
\text { ticipation in positive activities rather than } \\
\text { threatening ones }\end{array}$ & $\begin{array}{l}\text { Intrinsic interest } \\
\text { in novelty and } \\
\text { mastery }\end{array}$ & & \\
\hline Self-direction & $\begin{array}{l}\text { Independent thought } \\
\text { and action }\end{array}$ & $\begin{array}{l}\text { Independent thought and action through } \\
\text { choosing, creating and exploring. Self-direc- } \\
\text { tion values are derived from the need for } \\
\text { control and mastery and is our requirement } \\
\text { for autonomy and independence }\end{array}$ & & \multicolumn{2}{|c|}{$\begin{array}{l}\text { Reliance upon one's own judge- } \\
\text { ment and comfort with diversity of } \\
\text { existence }\end{array}$} \\
\hline
\end{tabular}

TABLE I: A Summary of Classifications in the Schwartz Values Model (Schwartz, 1992) 


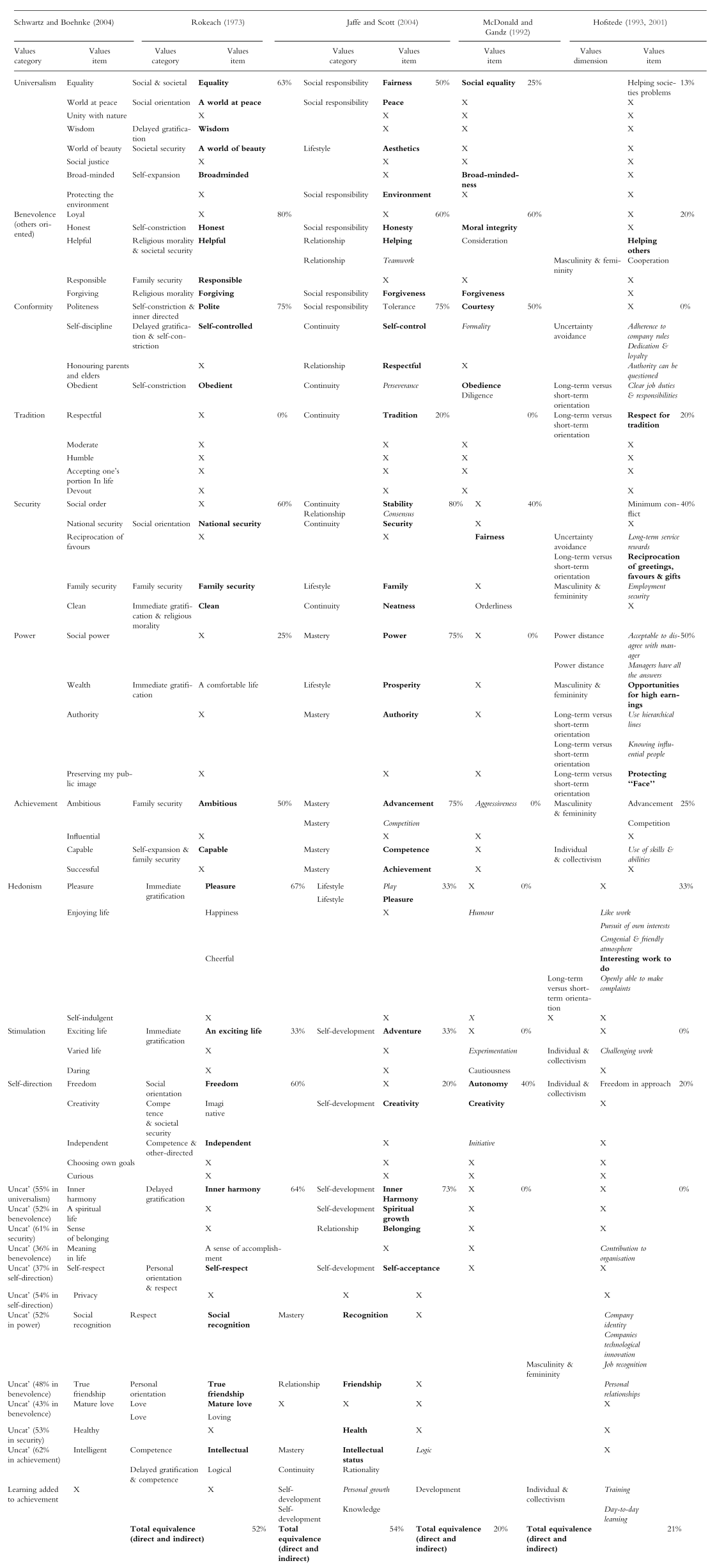

TABLE II: Detailed Comparisons of Values Items and Categories 


\begin{tabular}{|c|c|c|c|c|c|c|c|c|c|c|}
\hline Values categories & QS & & Arch & & Eng & & Value & & Ops & \\
\hline Universalism & & & & & 2 statements & $20 \%$ & 1 statement & $5 \%$ & & \\
\hline $\begin{array}{l}\text { Others oriented } \\
\text { (Benevolence) }\end{array}$ & 3 statements & $50 \%$ & & & 2 statements & $20 \%$ & 2 statements & $10 \%$ & & \\
\hline $\begin{array}{l}\text { Conformity } \\
\text { Tradition }\end{array}$ & 1 statement & $25 \%$ & 1 statement & $10 \%$ & & & 4 statements & $20 \%$ & & \\
\hline $\begin{array}{l}\text { Security } \\
\text { Power }\end{array}$ & & & & & 1 statement & $10 \%$ & 2 statements & $10 \%$ & & \\
\hline $\begin{array}{l}\text { Achievement } \\
\text { Hedonism } \\
\text { Stimulation } \\
\text { Self-direction }\end{array}$ & 1 statement & $25 \%$ & 9 statements & $90 \%$ & $\begin{array}{l}2 \text { statements } \\
1 \text { statement } \\
1 \text { statement } \\
1 \text { statement }\end{array}$ & $\begin{array}{l}20 \% \\
10 \% \\
10 \% \\
10 \%\end{array}$ & $\begin{array}{l}6 \text { statements } \\
1 \text { statement } \\
2 \text { statement } \\
2 \text { statement }\end{array}$ & $\begin{array}{l}30 \% \\
5 \% \\
10 \% \\
10 \%\end{array}$ & 8 statements & $100 \%$ \\
\hline
\end{tabular}

TABLE III: Content of Five Organisational Values Statements 


\begin{tabular}{|c|c|c|c|c|c|c|}
\hline & QS & Arch & Eng & Value & Ops & Ave \\
\hline Equality & -0.09 & 0.92 & 0.13 & 0.91 & 0.58 & 0.49 \\
\hline Peace between people & -0.48 & -0.02 & -0.37 & -0.69 & 0.03 & -0.31 \\
\hline Unity with nature & -2.31 & -1.55 & -1.01 & -2.19 & -2.19 & -1.85 \\
\hline Wise in issues of ethics & -0.92 & 0.86 & -0.51 & -0.19 & -0.64 & -0.28 \\
\hline Aesthetic beauty & -0.53 & 0.22 & -0.08 & 0.11 & -0.19 & -0.10 \\
\hline Social justice & -0.31 & 0.39 & -0.01 & 0.31 & -0.19 & 0.04 \\
\hline Broadminded & 0.97 & 0.92 & 0.70 & 0.41 & 1.25 & 0.85 \\
\hline Protecting the environment & -1.53 & -0.08 & -0.30 & -1.19 & -0.86 & -0.79 \\
\hline Inner harmony & -0.81 & 0.33 & -0.01 & -0.09 & -0.75 & -0.27 \\
\hline Loyal & 1.30 & 0.74 & 0.63 & 0.51 & 0.92 & 0.82 \\
\hline Honest & 1.74 & 1.16 & 1.49 & 0.91 & 1.47 & 1.35 \\
\hline Helpful & $\overline{0.85}$ & 0.63 & 0.78 & 0.11 & 1.36 & 0.75 \\
\hline Responsible & 1.69 & 1.22 & 1.28 & 0.91 & 1.03 & 1.22 \\
\hline Forgiving & $-\overline{0.76}$ & -0.37 & -0.80 & -0.79 & -0.19 & -0.58 \\
\hline Spirituality in work & -2.65 & -1.84 & -2.72 & -2.89 & -2.97 & -2.62 \\
\hline True friendship & 0.08 & 0.39 & 0.28 & 0.61 & 0.36 & 0.34 \\
\hline Meaning in work & $\underline{1.52}$ & 1.16 & 1.42 & 1.01 & 1.14 & 1.25 \\
\hline Respect for tradition & $-\overline{1.98}$ & -2.43 & -1.44 & -2.69 & -1.64 & -2.04 \\
\hline Moderate & -0.70 & -1.90 & -0.87 & -1.59 & -2.08 & -1.43 \\
\hline Humble & -0.81 & -1.37 & -1.44 & -1.49 & -1.42 & -1.31 \\
\hline Accepting my portion in life & -2.53 & -2.55 & -2.37 & -3.29 & -1.64 & -2.48 \\
\hline Faithful & 0.63 & 0.10 & 0.35 & 0.21 & 0.25 & 0.31 \\
\hline Politeness & 0.80 & 0.45 & 0.99 & 0.61 & 1.25 & 0.82 \\
\hline Self-discipline & 0.24 & -0.02 & 1.35 & 0.61 & 0.81 & 0.60 \\
\hline Honouring older more experienced others & -0.81 & -1.31 & -0.58 & -1.49 & 0.36 & -0.77 \\
\hline Dutiful and professional & 1.19 & 0.80 & 0.99 & 0.61 & 0.81 & 0.88 \\
\hline Social order & -0.31 & 0.04 & -0.15 & -0.39 & 0.03 & -0.16 \\
\hline Social security & -0.92 & -0.26 & -0.58 & -0.09 & 0.14 & -0.34 \\
\hline Reciprocation of favours & -0.70 & -1.02 & -1.51 & -0.39 & -0.86 & -0.90 \\
\hline Security of friends and family & 1.47 & 0.92 & $\underline{2.28}$ & 0.61 & 0.92 & 1.24 \\
\hline Clean & -0.09 & -0.90 & $-\overline{0.44}$ & -0.59 & 0.81 & -0.24 \\
\hline Sense of belonging & 0.30 & 0.10 & -0.44 & 0.11 & 0.14 & 0.04 \\
\hline Healthy & $\underline{1.58}$ & 0.92 & $\underline{2.20}$ & 1.01 & 1.36 & 1.41 \\
\hline Social power & $-\overline{2.87}$ & -3.08 & $-\overline{3.22}$ & -2.69 & -2.97 & -2.97 \\
\hline Wealth & 0.24 & -0.73 & -0.01 & 0.51 & -0.19 & -0.04 \\
\hline Authority & -0.15 & -0.61 & -0.80 & 0.11 & -0.64 & -0.42 \\
\hline Preserving public image & -1.65 & -1.67 & -0.80 & -0.09 & -0.53 & -0.95 \\
\hline Social recognition & -0.37 & -0.20 & 0.42 & 0.61 & 0.47 & 0.19 \\
\hline Ambitious & 1.19 & 0.69 & 0.13 & 1.11 & 0.81 & 0.78 \\
\hline Influential & 0.13 & -0.20 & -0.72 & 0.21 & -0.08 & -0.13 \\
\hline Capable & 1.13 & 1.10 & 1.56 & 1.21 & 1.36 & 1.27 \\
\hline Successful & 1.02 & 1.10 & $\overline{0.92}$ & $\underline{1.51}$ & 0.69 & 1.05 \\
\hline Intelligent & 0.69 & 1.04 & 0.99 & 0.91 & 1.36 & 1.00 \\
\hline Learning & 1.08 & 1.04 & 1.20 & 0.41 & 1.14 & 0.97 \\
\hline Pleasure & -0.92 & -0.84 & -1.01 & -0.29 & -1.86 & -0.99 \\
\hline Enjoying work & $\underline{1.63}$ & 1.39 & 0.99 & 0.81 & 1.14 & 1.19 \\
\hline Excitement in work & $\overline{1.47}$ & 1.04 & 0.56 & 1.01 & 0.25 & 0.86 \\
\hline Innovation & 1.24 & 1.39 & 0.92 & 1.01 & 0.58 & 1.03 \\
\hline Daring & -0.65 & -0.78 & -1.37 & -0.39 & -0.97 & -0.83 \\
\hline Freedom & 0.13 & 0.10 & -0.22 & 1.11 & 0.03 & 0.23 \\
\hline Creativity & 0.69 & 1.10 & -0.01 & 0.81 & 0.03 & 0.52 \\
\hline Independent & 1.02 & -0.08 & 0.49 & 0.61 & -0.31 & 0.35 \\
\hline Choosing own goals & -0.59 & -0.37 & -0.65 & 0.01 & 0.69 & -0.18 \\
\hline Curious & 0.08 & 0.98 & 0.13 & -0.09 & -0.75 & 0.07 \\
\hline Self-respect & 1.35 & 1.51 & 1.42 & 1.81 & 1.36 & 1.49 \\
\hline Privacy & -0.98 & $-\overline{0.55}$ & -0.15 & 0.31 & -0.97 & -0.47 \\
\hline High Importance (greater than $\underline{\mathbf{1 . 5}}$ ) & 5 & 1 & 3 & 2 & 0 & 0 \\
\hline Low Importance (less than $\mathbf{- 1 . 5}$ ) & 7 & 7 & 4 & 6 & 7 & 5 \\
\hline
\end{tabular}

The table shows values priorities within and between organisations, where bold represents low importance and underlined bold represents high importance.

TABLE IV: Centred Organisational Averages 


\begin{tabular}{|c|c|c|c|c|c|c|}
\hline & QS & Arch & Eng & Value & Ops & Ave \\
\hline Equality & 1.35 & 1.31 & 1.37 & 1.21 & 1.11 & 1.27 \\
\hline Peace between people & 1.38 & 1.29 & 1.81 & 2.56 & 1.11 & 1.63 \\
\hline Unity with nature & 1.10 & 1.46 & 1.63 & 1.67 & 1.33 & 1.44 \\
\hline Wise in issues of ethics & 1.62 & $\underline{0.79}$ & 1.24 & 1.47 & 1.03 & 1.23 \\
\hline Aesthetic beauty & 1.41 & $\overline{1.20}$ & 1.38 & 1.46 & $\underline{0.86}$ & 1.26 \\
\hline Social justice & 1.40 & 1.02 & 1.12 & 1.70 & $\underline{0.93}$ & 1.23 \\
\hline Broadminded & 1.13 & $\underline{0.99}$ & 1.60 & 1.74 & $\overline{0.92}$ & 1.28 \\
\hline Protecting the environment & 1.40 & $\overline{1.02}$ & 1.22 & 1.40 & $\overline{1.22}$ & 1.25 \\
\hline Inner harmony & 1.55 & 1.08 & 1.59 & 1.25 & 1.59 & 1.41 \\
\hline Loyal & 1.21 & $\underline{0.61}$ & 1.25 & 1.01 & $\underline{0.85}$ & $\underline{0.99}$ \\
\hline Honest & 1.06 & 1.03 & $\underline{0.65}$ & 1.36 & $\underline{0.73}$ & 0.97 \\
\hline Helpful & 1.13 & $\underline{0.74}$ & $\underline{0.95}$ & 1.17 & $\underline{0.57}$ & $\underline{0.91}$ \\
\hline Responsible & $\underline{0.97}$ & $\overline{1.03}$ & $\overline{0.64}$ & $\underline{0.68}$ & $\overline{0.81}$ & $\underline{0.83}$ \\
\hline Forgiving & $\overline{1.29}$ & 1.02 & $\overline{1.73}$ & $\overline{1.75}$ & $\overline{1.41}$ & $\overline{1.44}$ \\
\hline Spirituality in work & 1.52 & 1.49 & 1.47 & 1.51 & 1.66 & 1.53 \\
\hline True friendship & 1.63 & 1.61 & 1.43 & 1.58 & 1.99 & 1.65 \\
\hline Meaning in work & $\underline{0.96}$ & 1.29 & $\underline{0.83}$ & 1.23 & 1.01 & 1.06 \\
\hline Respect for tradition & $\overline{1.69}$ & 1.72 & $\overline{1.34}$ & 1.81 & $\underline{0.83}$ & 1.48 \\
\hline Moderate & 1.75 & 1.29 & 1.05 & 1.99 & $\overline{2.51}$ & 1.72 \\
\hline Humble & 1.43 & 1.22 & 1.84 & 2.46 & 1.86 & 1.76 \\
\hline Accepting my portion in life & 1.58 & 1.68 & 2.07 & 1.97 & 2.17 & 1.89 \\
\hline Faithful & 1.16 & 1.42 & 1.34 & 1.23 & 1.27 & 1.28 \\
\hline Politeness & 1.48 & 1.47 & $\underline{0.98}$ & $\underline{0.88}$ & $\underline{0.77}$ & 1.12 \\
\hline Self-discipline & 1.56 & 1.33 & $\overline{1.22}$ & $\overline{1.40}$ & $\overline{0.81}$ & 1.26 \\
\hline Honouring older more experienced others & 1.49 & 1.77 & 2.04 & 2.24 & $\overline{1.05}$ & 1.72 \\
\hline Dutiful and professional & 1.21 & 1.53 & 1.20 & 1.92 & 1.55 & 1.48 \\
\hline Social order & 1.30 & 1.45 & 1.02 & 1.26 & 1.21 & 1.25 \\
\hline Social security & 1.54 & 1.17 & 1.29 & 1.26 & 1.14 & 1.28 \\
\hline Reciprocation of favours & 1.48 & 1.57 & 1.74 & 1.51 & $\underline{0.47}$ & 1.35 \\
\hline Security of friends and family & 1.31 & 1.22 & 1.61 & 1.65 & $\overline{1.18}$ & 1.40 \\
\hline Clean & 1.35 & 1.44 & 1.22 & 1.14 & 1.22 & 1.27 \\
\hline Sense of belonging & 1.41 & 1.37 & 1.24 & 1.12 & 1.20 & 1.27 \\
\hline Healthy & 1.22 & 1.41 & 1.35 & 1.01 & 1.31 & 1.26 \\
\hline Social power & 1.78 & 1.80 & 1.55 & 1.61 & 2.41 & 1.83 \\
\hline Wealth & 1.27 & 1.60 & 1.71 & 1.20 & 1.21 & 1.40 \\
\hline Authority & 1.37 & 1.06 & 1.17 & 1.32 & 1.05 & 1.19 \\
\hline Preserving public image & 1.80 & 1.79 & 1.16 & 2.01 & 2.04 & 1.76 \\
\hline Social recognition & 1.38 & $\underline{0.99}$ & 1.08 & 1.14 & 1.51 & 1.22 \\
\hline Ambitious & 1.03 & $\overline{1.07}$ & 1.42 & 1.13 & 1.09 & 1.15 \\
\hline Influential & 1.15 & 1.26 & 1.59 & 1.37 & $\underline{0.76}$ & 1.23 \\
\hline Capable & $\underline{0.90}$ & 1.26 & $\underline{0.89}$ & $\underline{0.75}$ & $\overline{0.66}$ & $\underline{0.89}$ \\
\hline Successful & $\overline{0.92}$ & $\underline{0.98}$ & $\overline{0.71}$ & $\overline{0.87}$ & $\overline{0.84}$ & $\overline{0.87}$ \\
\hline Intelligent & $\overline{1.55}$ & $\overline{1.13}$ & $\overline{0.93}$ & $\overline{1.03}$ & $\overline{0.67}$ & $\overline{1.06}$ \\
\hline Learning & $\underline{0.76}$ & 1.31 & $\underline{0.98}$ & 1.35 & $\underline{0.64}$ & 1.01 \\
\hline Pleasure & 2.00 & 1.73 & 1.69 & 1.30 & 2.16 & 1.77 \\
\hline Enjoying work & 1.27 & $\underline{0.85}$ & $\underline{0.98}$ & 1.04 & $\underline{0.33}$ & $\underline{0.90}$ \\
\hline Excitement in work & $\underline{0.83}$ & 1.33 & 1.23 & $\underline{0.96}$ & 1.42 & 1.15 \\
\hline Innovation & $\overline{0.96}$ & $\underline{0.90}$ & $\underline{0.93}$ & $\overline{1.17}$ & 1.25 & 1.04 \\
\hline Daring & $\overline{1.23}$ & $\overline{1.25}$ & $\overline{1.25}$ & 2.10 & 1.62 & 1.49 \\
\hline Freedom & 1.43 & 1.58 & 1.16 & $\underline{0.85}$ & 1.09 & 1.22 \\
\hline Creativity & 1.42 & $\underline{0.86}$ & 1.12 & 1.67 & 1.06 & 1.23 \\
\hline Independent & 1.08 & $\overline{1.34}$ & 1.36 & 1.60 & 1.09 & 1.30 \\
\hline Choosing own goals & 1.22 & 1.62 & 1.59 & 1.69 & $\underline{0.54}$ & 1.33 \\
\hline Curious & 1.20 & 1.57 & 1.08 & 1.34 & $\overline{1.21}$ & 1.28 \\
\hline Self-respect & 1.35 & 1.03 & 1.19 & $\underline{0.91}$ & 1.12 & 1.12 \\
\hline Privacy & 1.25 & 1.70 & 1.32 & $\overline{1.34}$ & 1.51 & 1.42 \\
\hline High Alignment (less than $\underline{\mathbf{1 . 0}}$ ) & $\underline{7}$ & $\underline{9}$ & $\underline{11}$ & $\underline{7}$ & $\underline{18}$ & $\underline{16}$ \\
\hline Low Alignment (More than 1.7) & $\overline{4}$ & $\overline{6}$ & 7 & 12 & 7 & $\overline{2}$ \\
\hline
\end{tabular}

The table shows values alignment within organisations, where bold represents low alignment and underlined bold represents high alignment. 


\begin{tabular}{|c|c|c|c|}
\hline & $\begin{array}{c}\text { Not important } \\
\quad(-1,0,1)\end{array}$ & $\begin{array}{c}\text { Moderately } \\
\text { important }(2,3,4)\end{array}$ & $\begin{array}{c}\text { Very } \\
\text { important }(5,6,7)\end{array}$ \\
\hline Equality & 2 & 29 & 39 \\
\hline Peace between people & 3 & 40 & 27 \\
\hline Unity with nature & 23 & 38 & 9 \\
\hline Wise in issues of ethics & 3 & 34 & 27 \\
\hline Aesthetic beauty & 2 & 43 & 25 \\
\hline Social justice & 1 & 40 & 29 \\
\hline Broadminded & 2 & 17 & 51 \\
\hline Protecting the environment & 8 & 46 & 16 \\
\hline Inner harmony & 4 & 37 & 29 \\
\hline Loyal & 0 & 23 & 47 \\
\hline Honest & 0 & 13 & 57 \\
\hline Helpful & 0 & 23 & 47 \\
\hline Responsible & 0 & 11 & 59 \\
\hline Forgiving & 5 & 44 & 21 \\
\hline Spirituality in work & 35 & 30 & 5 \\
\hline True friendship & 4 & 28 & 38 \\
\hline Meaning in work & 0 & 9 & 61 \\
\hline Respect for tradition & 27 & 39 & 4 \\
\hline Moderate & 14 & 46 & 10 \\
\hline Humble & 13 & 48 & 9 \\
\hline Accepting my portion in life & 30 & 35 & 5 \\
\hline Faithful & 4 & 30 & 36 \\
\hline Politeness & 1 & 21 & 48 \\
\hline Self-discipline & 1 & 24 & 45 \\
\hline Honouring older more experienced others & 9 & 42 & 19 \\
\hline Dutiful and professional & 2 & 17 & 51 \\
\hline Social order & 3 & 41 & 26 \\
\hline Social security & 3 & 44 & 23 \\
\hline Reciprocation of favours & 9 & 49 & 12 \\
\hline Security of friends and family & 1 & 17 & 52 \\
\hline Clean & 4 & 40 & 26 \\
\hline Sense of belonging & 3 & 37 & 30 \\
\hline Healthy & 1 & 15 & 54 \\
\hline Social power & 40 & 27 & 3 \\
\hline Wealth & 1 & 15 & 54 \\
\hline Authority & 4 & 44 & 22 \\
\hline Preserving public image & 13 & 40 & 17 \\
\hline Social recognition & 2 & 36 & 32 \\
\hline Ambitious & 1 & 22 & 47 \\
\hline Influential & 5 & 33 & 32 \\
\hline Capable & 0 & 11 & 59 \\
\hline Successful & 0 & 20 & 50 \\
\hline Intelligent & 1 & 16 & 53 \\
\hline Learning & 0 & 11 & 59 \\
\hline Pleasure & 11 & 42 & 17 \\
\hline Enjoying work & 0 & 11 & 59 \\
\hline Excitement in work & 1 & 22 & 47 \\
\hline Innovation & 0 & 15 & 55 \\
\hline Daring & 6 & 49 & 15 \\
\hline Freedom & 2 & 35 & 33 \\
\hline Creativity & 1 & 29 & 40 \\
\hline Independent & 0 & 34 & 36 \\
\hline Choosing own goals & 2 & 42 & 26 \\
\hline Curious & 1 & 38 & 31 \\
\hline Self-respect & 0 & 9 & 61 \\
\hline Privacy & 9 & 41 & 20 \\
\hline Percentage ratio of total & $8.1 \%$ & $43.2 \%$ & $48.6 \%$ \\
\hline
\end{tabular}

The table shows the frequency with which values are scored as either not important, moderately important and very important across all organisational samples.

TABLE VI: Frequency Across Organisations 


\begin{tabular}{|c|c|c|c|}
\hline Organisation & $n$ Individuals & Significantly less important values & Significantly more important values \\
\hline QS & 18 & $\begin{array}{l}\text { Equality }(t=-2.091, \mathrm{df}=68, \boldsymbol{p}=\mathbf{0 . 0 4 0}, \text { two-tailed. Where } \\
\text { results had equal variance and a mean difference of }-0.741) \\
\text { Aesthetics }(t=-2.419, \mathrm{df}=68, \boldsymbol{p}=\mathbf{0 . 0 1 8}, \text { two-tailed. } \\
\text { Where results had equal variance and a mean difference of } \\
-0.901) \\
\text { Protecting the environment }(t=-3.089, \mathrm{df}=68, \\
\boldsymbol{p}=\boldsymbol{0 . 0 0 3} \text {, two-tailed. Where results had equal variance and a } \\
\text { mean difference of }-1.089) \\
\text { Inner harmony }(t=-2.117, \mathrm{df}=68, \boldsymbol{p}=\boldsymbol{0 . 0 3 8}, \text { two-tailed. } \\
\text { Where results had equal variance and a mean difference of } \\
-0.829)\end{array}$ & $\begin{array}{l}\text { Loyal }(t=2.260, \mathrm{df}=68, \boldsymbol{p}=\mathbf{0 . 0 2 7} \text {, two-tailed. Where } \\
\text { results had equal variance and a mean difference of } 0.629) \\
\text { Responsible }(t=2.380, \mathrm{df}=68, \boldsymbol{p}=\mathbf{0 . 0 2 0} \text {, two-tailed. } \\
\text { Where results had equal variance and a mean difference of } \\
0.556) \\
\text { Excitement in work }(t=2.205, \mathrm{df}=68, \boldsymbol{p}=\mathbf{0 . 0 3 1} \\
\text { two-tailed. Where results had equal variance and a mean } \\
\text { difference of } 0.699) \\
\text { Independent }(t=2.566, \mathrm{df}=68, \boldsymbol{p}=\mathbf{0 . 0 1 2} \text {, two-tailed. } \\
\text { Where results had equal variance and a mean difference of } \\
0.909)\end{array}$ \\
\hline Arch & 17 & $\begin{array}{l}\text { Clean }(t=-2.100, \mathrm{df}=68, \boldsymbol{p}=\mathbf{0 . 0 3 9} \text {, two-tailed. Where } \\
\text { results had equal variance and a mean difference of }-0.781) \\
\text { Wealth }(t=-2.120, \mathrm{df}=68, \boldsymbol{p}=\mathbf{0 . 0 3 8} \text {, two-tailed. Where } \\
\text { results had equal variance and a mean difference of }-0.849)\end{array}$ & $\begin{array}{l}\text { Aesthetics }(t=5.481, \mathrm{df}=48.647, \boldsymbol{p}=\mathbf{0 . 0 0 0} \text {, two-tailed. } \\
\text { Where results had equal variance and a mean difference of } \\
1.475) \\
\text { Protecting the environment }(t=2.311, \mathrm{df}=68, \boldsymbol{p}=\mathbf{0 . 0 2 4} \text {, } \\
\text { two-tailed. Where results had equal variance and a mean dif- } \\
\text { ference of } 0.854) \\
\text { Spirituality in work }(t=2.075, \mathrm{df}=68, \boldsymbol{p}=\mathbf{0 . 0 4 2}, \\
\text { two-tailed. Where results had equal variance and a mean } \\
\text { difference of } 0.863) \\
\text { Creativity }(t=2.662, \mathrm{df}=43.154, \boldsymbol{p}=\mathbf{0 . 0 1 1} \text {, two-tailed. } \\
\text { Where results had equal variance and a mean difference of } \\
\text { 0.748). Although this value is not normally distributed } \\
\text { (Shapiro-Wilk Sig. } 0.05)\end{array}$ \\
\hline Eng & 16 & $\begin{array}{l}\text { Ambitious }(t=-2.363, \mathrm{df}=68, \boldsymbol{p}=\mathbf{0 . 0 2 1} \text {, two-tailed. } \\
\text { Where results had equal variance and a mean difference of } \\
-0.774) \\
\text { Creativity }(t=-2.430, \mathrm{df}=68, \boldsymbol{p}=\mathbf{0 . 0 1 8} \text {, two-tailed. } \\
\text { Where results had equal variance and a mean difference of } \\
-0.864)\end{array}$ & $\begin{array}{l}\text { Unity with nature }(t=3.269, \mathrm{df}=68, \boldsymbol{p}=\mathbf{0 . 0 0 2} \text {, two-tailed. } \\
\text { Where results had equal variance and a mean difference of } \\
1.333) \\
\text { Protecting the environment }(t=2.010, \mathrm{df}=68, \boldsymbol{p}=\mathbf{0 . 0 4 8} \text {, } \\
\text { two-tailed. Where results had equal variance and a mean dif- } \\
\text { ference of } 0.765) \\
\text { Self-discipline }(t=2.428, \mathrm{df}=68, \boldsymbol{p}=\boldsymbol{0 . 0 1 8} \text {, two-tailed. } \\
\text { Where results had equal variance and a mean difference of } \\
0.918)\end{array}$ \\
\hline Value & 10 & $\begin{array}{l}\text { Helpful }(t=-2.225, \mathrm{df}=68, \boldsymbol{p}=\mathbf{0 . 0 2 9}, \text { two-tailed. Where } \\
\text { results had equal variance and a mean difference of }-0.726) \\
\text { Learning }(t=-2.108, \mathrm{df}=68, \boldsymbol{p}=\mathbf{0 . 0 3 9}, \text { two-tailed. Where } \\
\text { results had equal variance and a mean difference of }-0.743)\end{array}$ & $\begin{array}{l}\text { Freedom }(t=2.523, \mathrm{df}=68, \boldsymbol{p}=\boldsymbol{0 . 0 1 4} \text {, two-tailed. Where } \\
\text { results had equal variance and a mean difference of } 1.107) \\
\text { Privacy }(t=2.113, \mathrm{df}=68, \boldsymbol{p}=\mathbf{0 . 0 3 8} \text {, two-tailed. Where } \\
\text { results had equal variance and a mean difference of } 1.024) \text {. } \\
\text { Although this value is not normally distributed (Shapiro-Wilk } \\
\text { Sig. } 0.038 \text { ) }\end{array}$ \\
\hline Ops & 9 & $\begin{array}{l}\text { Curious }(t=-2.314, \mathrm{df}=68, \boldsymbol{p}=\mathbf{0 . 0 2 4} \text {, two-tailed. Where } \\
\text { results had equal variance and a mean difference of }-1.094)\end{array}$ & $\begin{array}{l}\text { Helpful }(t=2.109, \mathrm{df}=68, \boldsymbol{p}=\mathbf{0 . 0 3 9}, \text { two-tailed. Where } \\
\text { results had equal variance and a mean difference of } 0.722) \\
\text { Honouring older more experienced others }(t=2.163 \text {, } \\
\mathrm{df}=68, \boldsymbol{p}=\mathbf{0 . 0 3 4}, \text { two-tailed. Where results had equal vari- } \\
\text { ance and a mean difference of } 1.362) \\
\text { Clean }(t=2.749, \mathrm{df}=68, \boldsymbol{p}=\mathbf{0 . 0 0 8} \text {, two-tailed. Where re- } \\
\text { sults had equal variance and a mean difference of } 1.282) \\
\text { Choosing own goals }(t=4.456, \mathrm{df}=31.322, \boldsymbol{p}=\mathbf{0 . 0 0 0} \text {, } \\
\text { two-tailed. Where results had equal variance and a mean dif- } \\
\text { ference of } 1.170)\end{array}$ \\
\hline
\end{tabular}

TABLE VII: Statistical Value Differences Among Five Organisations 